JOSÉ SÉRGIO DE ARRUDA GONÇALVES

Análise da expressão gênica dos receptores de estrógeno (ERa e ERß) e progesterona (PR) em oócitos e células do cumulus nas diferentes fases do ciclo estral em cães

SÃO PAULO

2007 
JOSÉ SÉRGIO DE ARRUDA GONÇALVES

\section{Análise da expressão gênica dos receptores de estrógeno (ERa e $E R \beta)$ e progesterona (PR) em oócitos e células do cumulus nas diferentes fases do ciclo estral em cães}

Dissertação apresentada ao Programa de PósGraduação em Reprodução Animal da Faculdade de Medicina Veterinária e Zootecnia da Universidade de São Paulo para obtenção do título de Mestre em Medicina Veterinária

Departamento:

Reprodução Animal

Área de concentração:

Reprodução Animal

Orientador:

Prof. Dr. José Antônio Visintin

São Paulo

2007 
Autorizo a reprodução parcial ou total desta obra, para fins acadêmicos, desde que citada a fonte.

DADOS INTERNACIONAIS DE CATALOGAÇÃO-NA-PUBLICAÇÃO

(Biblioteca Virginie Buff D’Ápice da Faculdade de Medicina Veterinária e Zootecnia da Universidade de São Paulo)

T.1878 Gonçalves, José Sérgio de Arruda

FMVZ Análise da expressão gênica dos receptores de estrógeno (ER $\alpha$ e $E R \beta$ ) e progesterona (PR) em oócitos e células do cumulus nas diferentes fases do ciclo estral em cães / José Sérgio de Arruda Gonçalves. -- São Paulo: J. S. A. Gonçalves, 2007. $55 \mathrm{f}$. : il.

Dissertação (mestrado) - Universidade de São Paulo. Faculdade de Medicina Veterinária e Zootecnia. Departamento de Reprodução Animal, 2007.

Programa de Pós-Graduação: Reprodução Animal.

Área de concentração: Reprodução Animal.

Orientador: Prof. Dr. José Antônio Visintin.

1. Oócito. 2. Cumulus. 3. Estrógeno. 4. Progesterona. 5. Receptores. 6. Cães. I. Título. 


\section{UNIVERSIDADE DE SÃO PAULO \\ Faculdade de Medicina Veterinária e Zootecnia \\ Cidade Universitária "Armando de Salles Oliveira" \\ Comissão Bioética}

\section{CERTIFICADO}

Certificamos que o Projeto intitulado "Análise da expressão gênica diferencial dos receptores de estrógeno (Er $\alpha$ e ER $\beta$ ) e progesterona (pr) em oócitos e células do cumulus nas diferentes fases do ciclo estral em cães", protocolo n"558/2004, utilizando 40 cães, sob a responsabilidade do Prof. Dr. José Antonio Visintin, está de acordo com os princípios éticos de experimentação animal da Comissão de Bioética da Faculdade de Medicina Veterinária e Zootecnia da Universidade de São Paulo e foi aprovado "ad referendun".

(We certify that the Research "Differential genetic expression of estrogen (Er $\alpha$ e ER $\beta$ ) and progesterone receptors on oocytes and cumulus cells on different phases of the estrus cycle in dogs ", protocol number 558/2004, utilizing 40 dogs, under the responsibility of Prof. Dr. José Antonio Visintin agree with Ethical Principles in Animal Research adopted by Bioethic Commission of the Faculty of Veterinary Medicine and Zootechny of University of São Paulo and was approved "ad referendun", meeting).

São Paulo, 21 de dezembro de 2004

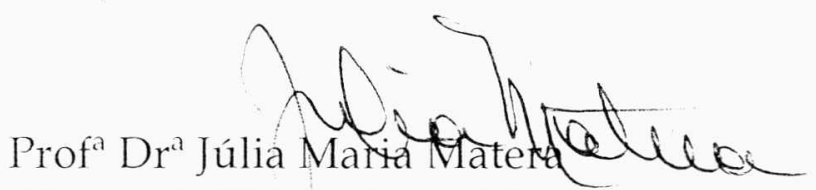

Presidente da Comissão de Bioética

FMVZYUSP 


\section{FOLHA DE AVALIAÇÃO}

Nome: GONÇALVES, José Sérgio de Arruda

Título: Análise da expressão gênica dos receptores de estrógeno (ERa e ERß) e progesterona (PR) em oócitos e células do cumulus nas diferentes fases do ciclo estral em cães

Dissertação apresentada ao Programa de PósGraduação em Reprodução Animal da Faculdade de Medicina Veterinária e Zootecnia da Universidade de São Paulo para obtenção do título de Mestre em Medicina Veterinária

Data:

Banca Examinadora

Prof. Dr. Instituição:

Assinatura: Julgamento:

Prof. Dr. Instituição:

Assinatura: Julgamento:

Prof. Dr. Instituição:

Assinatura: Julgamento: 
"O temor do Senhor é o princípio da sabedoria"

Provérbios 1:7 
Dedico ao meu avô Sérgio, por seu exemplo de vida.

$E$ aos meus pais e irmãos.

Essa vitória é de vocês! 


\section{RESUMO}

GONÇALVES, J. S. A. Análise da expressão gênica diferencial dos receptores de estrógeno (ero e er $\beta$ ) e progesterona (pr) em oócitos e células do cumulus nas diferentes fases do ciclo estral em cães. [A. Analysis of differential gene expression of estrogen (era and er $\beta$ ) and progesterone (pr) receptors in oocytes and cumulus cells on different phases of the estrous cycle in dogs]. 2007. $55 \mathrm{f}$. Dissertação (Mestrado em Medicina Veterinária) - Faculdade de Medicina Veterinária e Zootecnia, Universidade de São Paulo, São Paulo, 2007.

O objetivo do presente estudo foi analisar a expressão gênica dos receptores de estrógeno (ERa e ERß) e progesterona (PR) em oócitos e células do cumulus de cadelas nas diferentes fases do ciclo estral. Ovários de cadelas previamente avaliadas e submetidas à ovário-histerectomia foram fatiados, sob refrigeração, em PBS com 10\% de SFB. No momento imediatamente pré-cirúrgico foi colhido sangue da cadela, que foi submetido posteriormente à dosagem de estradiol e progesterona. As cadelas foram agrupadas nas diferentes fases do ciclo estral de acordo com a avaliação prévia por colpocitologia, colposcopia e dosagem sérica de progesterona. Os oócitos recuperados após o fatiamento foram denudados mecanicamente. Oócitos e células do cumulus foram criopreservados separadamente e posteriormente foram submetidas a PCR em tempo real para quantificação relativa dos genes de interesse. A expressão gênica de $E R \alpha, E R \beta$ e PR em oócitos e células do cumulus não foi diferente nas fases do ciclo estral. Foi possível, pela primeira vez, relatar a presença de ERa e ERß em oócitos de cadelas.

Palavras-chave: Oócito, Cumulus. Estrógeno. Progesterona. Receptores. Cães. 


\begin{abstract}
GONÇALVES, J. S. A. A. Analysis of differential gene expression of estrogen (er $\alpha$ and er $\beta$ ) and progesterone (pr) receptors in oocytes and cumulus cells on different phases of the estrous cycle in dogs. [Análise da expressão gênica diferencial dos receptores de estrógeno (er $\alpha$ e er $\beta$ ) e progesterona (pr) em oócitos e células do cumulus nas diferentes fases do ciclo estral em cães]. 2007. $55 \mathrm{f}$. Dissertação (Mestrado em Medicina Veterinária) - Faculdade de Medicina Veterinária e Zootecnia, Universidade de São Paulo, São Paulo, 2007.
\end{abstract}

The objective of the present study was to analyze the gene expression of estrogen (ER $\alpha$ and $E R \beta)$ and progesterone (PR) receptors in oocytes and cumulus cells on different phases of the estrous cycle in dogs. Ovaries from selected bitches were recovered after ovary-hysterectomy and sliced at low temperatures in PBS supplemented with 10\% FCS. Immediately after surgery, blood samples were harvested for measurement of estrogen and progesterone serum concentration. Bitches were grouped within different phases of the estrous cycles, according to previous evaluation of colpocytology, colposcopy and serum progesterone levels. Oocytes recovered after slicing were mechanically denuded. Isolated oocytes and cumulus cells were cryopreserved and submitted to RT-PCR followed by a real time PCR for relative quantification of gene expression. Gene expression of ERa, ER $\beta$ and PR in oocytes and cumulus cells was not different among phases of the estrous cycles. For the first time it was possible to demonstrate ERa and ERß in dog oocytes.

Key-words: Oocyte. Cumulus. Estrogen. Progesterone. Receptors. Dogs. 


\section{SUMÁRIO}

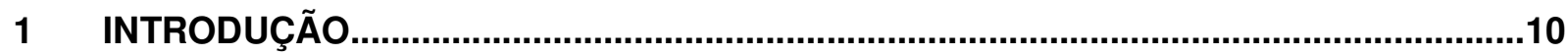

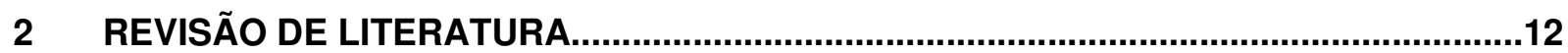

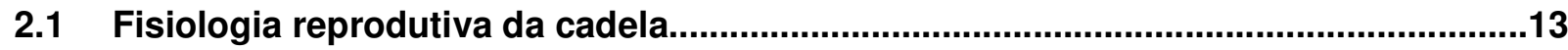

2.2 Influência dos hormônios esteróides na maturação in vitro de oócitos (MIV)..........16

2.3 Receptores de estrógeno (Era e Erß) e progesterona (PR)......................................17

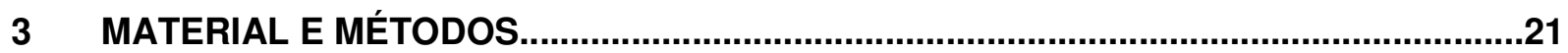

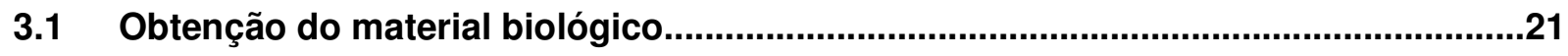

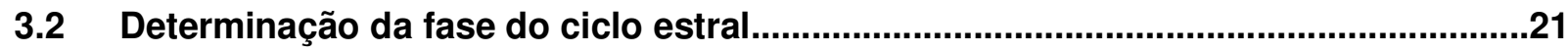

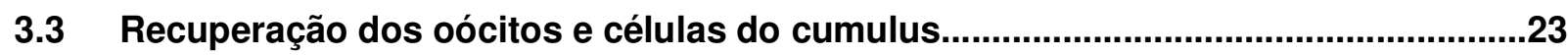

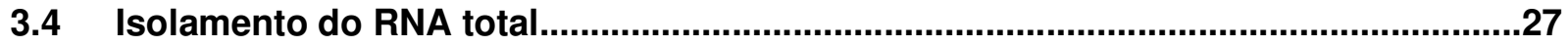

3.4.1 Isolamento do RNA total de oócitos e de células do cumulus...................................27

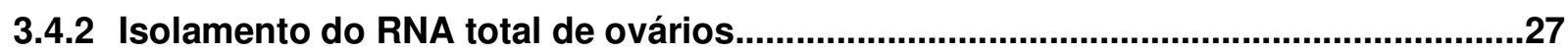

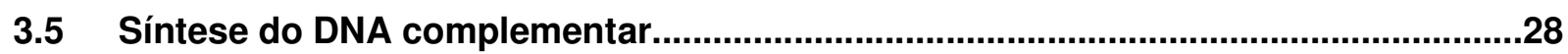

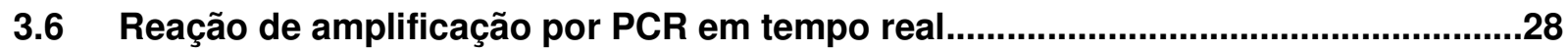

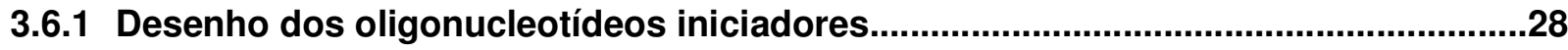

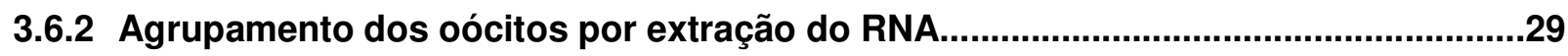

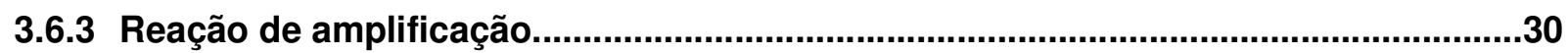

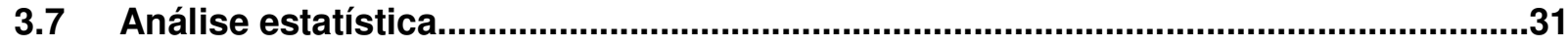

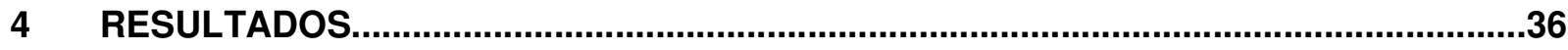

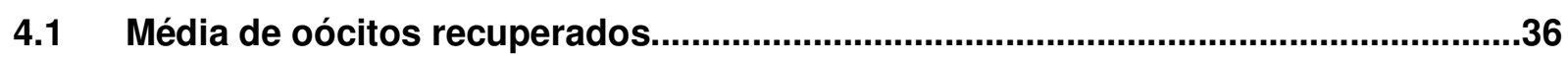

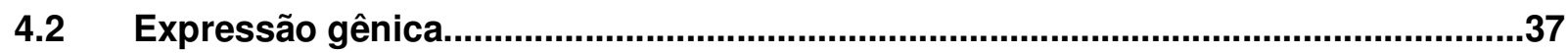

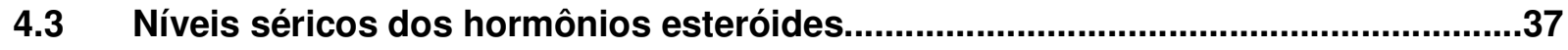

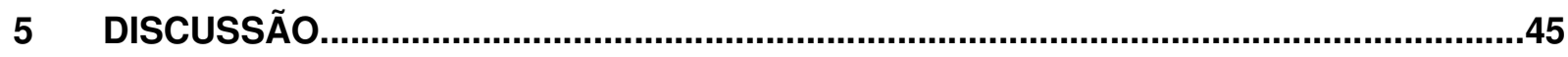

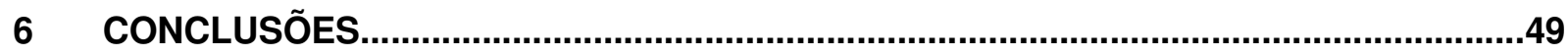

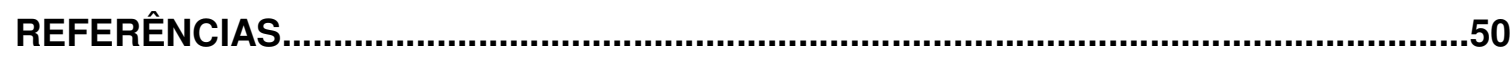




\section{INTRODUÇÃO}

O acentuado progresso da biotecnologia nas últimas décadas se mostra evidente na área da reprodução animal. Técnicas como a transferência de embriões (TE), a produção in vitro de embriões (PIV) e a transgenia têm cooperado para consolidar conhecimentos básicos sobre a fisiologia reprodutiva das espécies animais além de contribuirem com o melhoramento genético e reprodutivo nas espécies de produção. Os conhecimentos acerca da fisiologia reprodutiva básica na espécie canina apresentam muitas lacunas, fato que cerceia o desenvolvimento das biotécnicas reprodutivas nesta espécie.

A importância dos cães para a sociedade moderna é marcante. O estreitamento do relacionamento entre esses animais e seus proprietários é crescente, principalmente em grandes centros urbanos, nos quais os seres humanos vivem em moradias com espaço cada vez menor. Assim, antes relegados a viver apenas nos quintais, os cães têm compartilhado cada vez mais do convívio e da rotina doméstica, sendo considerados verdadeiros "membros da família". Por isso, normalmente, não são medidos esforços financeiros para investimento no bem-estar desses animais. A criação de cães de alto valor comercial e elevado padrão genético desenvolveu-se sensivelmente nos últimos anos. Com isso, o interesse pela elevação da performance reprodutiva desses cães e pela utilização de biotécnicas como a criopreservação de gametas é evidente.

Outro interesse no estudo da fisiologia reprodutiva dos cães é a sua utilização como modelo experimental, estabelecendo referências fisiológicas que podem ser extrapoladas para outros canídeos, auxiliando nos programas de preservação de espécies ameaçadas de extinção. A TE e a PIV são potencialmente as mais poderosas ferramentas disponíveis atualmente para o estudo da fecundação e da preservação de material genético de espécies em risco de extinção (LUVONI, 2000).

A evolução da PIV depende do estabelecimento de protocolos eficientes e viáveis de capacitação espermática e, principalmente, de maturação in vitro de oócitos (MIV). A baixa competência meiótica de oócitos caninos é o principal obstáculo para a produção in vitro de embriões (VANNUCCHI, 2003). Para tal, é necessário mimetizar in vitro as condições e estímulos aos quais os gametas são submetidos in vivo, bem como compreender as etapas fisiológicas dos processos reprodutivos. O padrão da endocrinologia reprodutiva das cadelas difere de todas as 
outras espécies domésticas. Em cadelas ocorre luteinização pré-ovulatória, com isso o oócito é submetido a níveis crescentes de progesterona ainda no ambiente folicular, à medida que decrescem os níveis séricos de estrógeno.

A influência da suplementação hormonal foi demonstrada por diversos autores como uma das perspectivas para mimetizar, nos meios de MIV, os mecanismos que ocorrem in vivo. Assim, os hormônios esteróides desempenham papel de protagonistas sobre o desenvolvimento dos oócitos durante as maturações citoplasmática e nuclear. Entretanto, os exatos mecanismos pelos quais os hormônios esteróides exercem influência sobre os complexos cumulus-oócitos (COCs) nos cães permanecem obscuros. Sabe-se que estão envolvidos receptores intracelulares, que alteram sua conformação quando ligados aos hormônios esteróides. O esclarecimento da expressão dos receptores dos hormônios estrógeno e progesterona nas células do cumulus e em oócitos estabelecerá referência para a suplementação hormonal dos meios de MIV para oócitos colhidos nas diferentes fases do ciclo estral em cães, além de fornecer bases fisiológicas ainda não dominadas na espécie canina.

Diante do exposto, os objetivos do presente trabalho foram:

1) Verificar a expressão gênica de receptores dos hormônios esteróides progesterona (PR) e estrógeno (ER $\alpha$ e $E R \beta)$ em oócitos e células do cumulus de cadelas nas diferentes fases do ciclo estral.

2) Comparar a expressão de RNAm de PR, ER $\alpha$ e ER $\beta$ em oócitos e células do cumulus de cadelas no proestro, estro, diestro e anestro.

3) Comparar a média dos níveis séricos de estradiol e progesterona entre as diferentes fases do ciclo estral. 


\section{REVISÃO DE LITERATURA}

O acentuado progresso da biotecnologia nas últimas décadas se mostra evidente na área da reprodução animal. O desenvolvimento de técnicas como a transferência de embriões (TE), a produção in vitro de embriões (PIV), a criopreservação de gametas, a clonagem por transferência nuclear (TN) e a transgenia em mamíferos tem contribuído para o melhor conhecimento da fisiologia reprodutiva das espécies animais, tornando possível a preservação do material genético (OTOl et al., 2000).

Os conhecimentos acerca da fisiologia reprodutiva dos cães estão sensivelmente defasados quando comparados aos animais de produção. A importância econômica destas espécies estimula incentivos maciços em pesquisas na área da reprodução. A PIV de embriões tem sido utilizada em larga escala nas espécies bovina e suína, fornecendo material necessário para o desenvolvimento de biotécnicas como a clonagem e a transgenia. A defasagem e a inconstância dos resultados na MIV em cães prejudicam as pesquisas destas biotécnicas, que requerem conhecimento sólido sobre o desenvolvimento e o cultivo embrionário.

A área de reprodução em cães necessita de linhas de pesquisa com objetivo de compreender e estabelecer referências para a fisiologia da espécie. Apesar da necessidade de desenvolver e aplicar técnicas de reprodução assistida, a limitação dos conhecimentos sobre os processos reprodutivos é patente (VANNUCCHI, 2003).

Oócitos de cadelas podem ser maturados, fecundados e cultivados in vitro, porém com índices bastante inferiores aos alcançados em outras espécies domésticas (LUVONI, 2000). Em bovinos a proporção de oócitos maturados in vitro até metáfase II (MII) está em torno de 80\% (BEVERS et al., 1997) e a de blastocistos após fecundação e cultivo in vitro de 50 a 80\% (BORDIGNON et al., 1997; BLONDIN et al., 2002; RIZOS et al., 2002). Em cães, os índices de oócitos que atingem MII estão em torno de 20\% (FARSTAD, 2000b) e os de blastocistos bastante inferiores, sendo reportada apenas uma prenhez após a transferência de embrião PIV (ENGLAND et al., 2001).

Um dos interesses no estudo dos processos reprodutivos dos cães se deve à utilização de seu ciclo reprodutivo como modelo experimental, estabelecendo referências fisiológicas que podem ser extrapoladas para espécies de carnívoros 
ameaçadas de extinção (LUVONI, 2000). A utilização das biotécnicas da reprodução para desenvolver protocolos de cultivo e de preservação de gametas é de grande valia para estas espécies, possibilitando a criação de bancos de germoplasma ou os chamados "zoológicos criopreservados" (DURRANT, 1990; GUIMARÃES, 2004). A TE e a FIV são potencialmente as mais poderosas ferramentas disponíveis atualmente para o estudo da fecundação e da preservação de material genético de espécies em risco de extinção (LUVONI, 2000).

Métodos contraceptivos mais seguros, acessíveis e eticamente aceitáveis também têm sido desenvolvidos, já que a esterilização cirúrgica em cães e principalmente em animais selvagens pode ser inviável devido aos riscos anestésicos, aos custos e a dificuldade de contenção (JEWGENOW et al., 2004). Em cães, muitos dos procedimentos relacionados à reprodução tornam-se impeditivos para uso em larga escala pela necessidade de procedimentos cirúrgicos, como a TE (TSUTSUI et al., 2000).

A evolução da PIV de embriões depende do estabelecimento de protocolos eficientes e viáveis de capacitação espermática e principalmente de MIV. A baixa competênca meiótica dos oócitos caninos maturados in vitro é o maior obstáculo para a PIV de embriões para futuros programas de preservação de canídeos ameaçados de extinção (OTOl et al., 1999).

\subsection{Fisiologia reprodutiva da cadela}

As cadelas são monoéstricas e os efeitos da sazonalidade não são observados na maioria das raças, exceto na raça Basenji, cujas fêmeas apresentam apenas um ciclo estral por ano, durante o outono no hemisfério norte (FARSTAD, 2000b). Diferentemente da maioria das outras espécies mamíferas, em que os estrógenos predominam em folículos pré-ovulatórios, nas cadelas ocorre luteinização pré-ovulatória, assim os folículos na fase de proestro são expostos a crescentes níveis de progesterona (CONCANNON et al., 1975).

Outro aspecto que diferencia a fisiologia reprodutiva das cadelas é o estágio de maturação nuclear do oócito à ovulação. Enquanto na maioria das espécies o oócito sofre meiose até metáfase II (MII) antes de ser liberado para o oviduto, em 
cadelas a ovulação ocorre com o oócito em estágio de vesícula germinativa (prófase I) (CONCANNON et al., 1989; GUÉRIN, 1998; FARSTAD 2000b).

O oócito sofre quebra da vesícula germinativa rapidamente e completa a primeira divisão meiótica entre 48 e 72 horas após a ovulação e permanece apto à fecundação por aproximadamente 108 horas (YAMADA et al., 1992).

As células do cumulus, que são um subtipo de células da granulosa, permanecem aderidas aos oócitos mesmo após a ovulação (RENTON et al., 1991). As células do cumulus retém algumas propriedades das demais células da granulosa como a responsividade às gonadotrofinas e a secreção de esteróides (MINGOTI, 1999).

A comunicação entre as células do complexo cumulus-oócito (COC) ocorre através de projeções da membrana citoplasmática das células do cumulus que atravessam a zona pelúcida e formam pequenos canais (junções gap) que fazem contato com o citoplasma do oócito. Ao contrário do que ocorre em ratas, as junções gap dos COCs de cadelas permanecem abertas no momento da ovulação (GILULA et al., 1978). No bovino, verifica-se perda evidente das junções gap das células do cumulus durante a retomada da meiose, mas as ligações remanescentes permanecem funcionais até a MII (SUTOVSKY et al., 1993). Esses mesmos autores relataram que as junções gap são essenciais para o transporte de nutrientes e de moléculas mensageiras como o AMP cíclico (cAMP) das células do cumulus para os oócitos.

Poucos momentos antes da ovulação, oócitos e células do cumulus mostraram sinais evidentes de comunicação entre si. Após 3 dias de ovulação (oócitos maturos), os oócitos estão totalmente desconectados das células do cumulus (LESEGNO et al., 2007) ${ }^{1}$. Desta maneira tem sido proposto que a diminuição das junções gap é um fato cronologicamente relacionado à maturação oocitária, assim, essas junções teriam importante papel na coordenação entre as maturações nuclear e citoplasmática (WERT; LARSEN, 1989; RODRIGUEZ; FARIN, 2004).

As junções gap permitem a transferência de nutrientes, precursores metabólicos e citocinas entre as células do cumulus e o oócito, além de transmitirem sinais elétricos e transportarem moléculas mensageiras das células foliculares ao oócito. Segundos-mensageiros como cAMP e cálcio podem passar através das junções gap para as células vizinhas, propagando sinais induzidos por estimulação 
hormonal. A formação das junções gap é estimulada por estrógenos (LAWRENCE et al., 1978; LUVONI et al., 2001; SCHAMS; BERISHA, 2002). Simpson et al. (1977) relataram que moléculas com peso molecular até 1200 daltons podem ser transportados através das junções gap.

Em bovinos, a desconexão entre as junções gap dos COCs ocorre simultaneamente à ruptura da vesícula germinativa (HYTTEL, 1997).

Luvoni et al. (2001) mostraram que $89 \%$ das junções gap estavam abertas em COCs de cadelas em proestro e 67\% delas permaneceram abertas após 24 horas de MIV oocitária, porém não houve evidência de permeabilidade em COCs de cadelas em anestro. Observaram também correlação positiva entre a presença das junções gap permeáveis e a competência meiótica em COCs de cadelas no final do proestro.

Em cadelas, a maturação nuclear até MII apresenta índices variáveis nos diferentes meios de maturação e suplementações na MIV. Outros fatores que podem influenciar os índices de MIV são a idade das cadelas doadoras de oócitos (NICKSON et al., 1993), a raça (DURRANT et al., 1998), o diâmetro dos oócitos (OTOI et al., 2000; OTOI et al., 2001) e a qualidade dos oócitos (HEWITT; ENGLAND, 1998b).

A influência da fase do ciclo estral é controversa. Yamada et al. (1993) relataram que oócitos de cadelas em anestro não mostraram tendência a maturação por mais de 144 horas de cultivo in vitro. Nickson et al. (1993) observaram que o período de diestro é prejudicial ao desenvolvimento oocitário. Otoi et al. (2001) relataram que COCs de cadelas em fase folicular atingem a maturação nuclear com maiores índices em relação às fases luteínica e anestro. Outros estudos, no entanto, apresentaram índices semelhantes de maturação nuclear em oócitos de animais nas diferentes fases do ciclo estral (HEWITT; ENGLAND, 1998a; RODRIGUES; RODRIGUES, 2003). 


\subsection{Influência dos hormônios esteróides na maturação in vitro de oócitos (MIV)}

O meio de maturação de oócitos mais utilizado em cadelas é o TCM199 (NICKSON et al., 1993; HEWITT; ENGLAND, 1998b), que pode ser suplementado com hormônios esteróides e outras substâncias favoráveis ao desenvolvimento oocitário como o soro fetal bovino (FCS) e a albumina sérica bovina (BSA). Diversos autores relataram influência dos hormônios esteróides sobre a MIV de oócitos caninos.

Willingham-Rocky et al. (2003) demonstraram que o TCM199 suplementado com $2 \mu \mathrm{g} / \mathrm{ml}$ de progesterona apresentou $23 \%$ de oócitos em MII.

A adição de estradiol ao meio MIV não induziu efeito significativo na retomada da meiose de oócitos de cadelas em anestro (HEWITT; ENGLAND, 1997). Entretanto, Vannucchi et al. (2003), em estudo que utilizou co-cultivo com células do oviduto em cadelas na fase de anestro, relataram que a suplementação do meio MIV com progesterona apresentou efeito benéfico na MIV.

A suplementação com soro de cadela também tem sido estudada por diversos autores. Soros de animais em diferentes fases do ciclo estral foram utilizados por Otoi et al. (1999) para suplementação do meio TCM199. Este estudo demonstrou que os índices de maturação de oócitos cultivados em meio suplementado com soro de cadela em estro foram melhores do que nos suplementados com soro de cadela em anestro. O soro de cadela em estro apresenta nível superior de estrógeno e progesterona em relação ao de animal em anestro. O meio suplementado com soro de cadela em estro proporcionou a maturação de 16,3\% dos oócitos até MIl. Nickson et al. (1993) relataram que $39 \%$ dos COCs cultivados em meio TCM199 suplementado com $10 \%$ de soro de cadela em estro e $20 \mu \mathrm{g} / \mathrm{ml}$ de estradiol expulsaram o primeiro corpúsculo polar após 24 horas de cultivo. Os autores postularam que os oócitos caninos requerem desenvolvimento com altas concentrações de estrógeno para maturação nuclear.

Os hormônios esteróides em mamíferos são produzidos pelas células do ovário, sendo os estrógenos pelos folículos e a progesterona pelo corpo lúteo (SCHAMS; BERISHA, 2002). Entretanto, em cadelas, células de folículos terciários em desenvolvimento também produzem progesterona à medida que se aproxima do momento da ovulação. Níveis crescentes de progesterona e decrescentes de estrógeno são produzidos antes da ovulação, momento em que não há corpo lúteo 
ativo (OLSON et al., 1984). A influência dos hormônios esteróides nos processos de MIV sinaliza os possíveis mecanismos de atuação destes hormônios nos COCs.

\subsection{Receptores de estrógeno (ERa e ERß) e progesterona (PR)}

Os receptores são proteínas que contêm sítios específicos aos quais os hormônios se ligam. As ligações modificam a conformação do receptor, iniciando a síntese do RNAm específico, que é translocado ao citoplasma, onde há síntese de proteínas específicas, promovendo a resposta celular (SWENSON; REECE, 1996).

Os receptores de progesterona (PR) e estrógeno (Era e Erß) apresentam localização nuclear (MOSSELMAN et al., 1996). Fazem parte da superfamília dos receptores nucleares que tem, como característica, arquitetura estrutural semelhante (Figura 1).

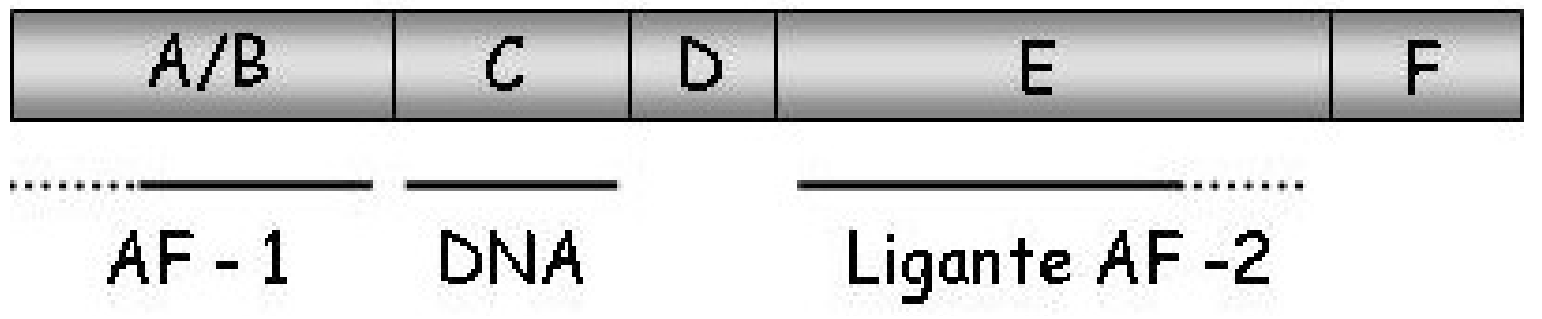

Figura 1- Estrutura dos receptores de esteróides. Evidenciam-se os domínios A/B, C, $\mathrm{D} / \mathrm{E} / \mathrm{F}$

São compostos por 3 domínios independentes que apresentam diferentes funções: 1) o terminal $\mathrm{NH} 2$ ou domínio $A / B$ - região do receptor envolvida em interações proteína-proteína e ativação transcricional dos genes-alvo. Possui função de ativação independente do ligante (AF-1). 2) domínio de ligação ao DNA (DBD) ou domínio C - contém uma estrutura com 2 "dedos de zinco", que desempenha um importante papel na dimerização e ligação dos receptores a seqüencias de DNA específicas. 3) domínio D/E/F ou domínio de acoplamento ao ligante (LBD) - medeia 
- acoplamento ao ligante, dimerização do receptor, translocação nuclear e transativação da expressão do gene-alvo. Possui função de ativação dependente do ligante (AF-2) (EVANS, 1988).

O acoplamento de um ligante ao receptor desencadeia mudanças conformacionais no receptor que levam, via inúmeros eventos, à mudanças no índice de transcrição dos genes regulados pelo ligante. Esses eventos, e a ordem na qual os mesmos ocorrem, não estão completamente compreendidos, mas eles incluem dimerização do receptor, interação receptor-DNA, recrutamento e interação com coativadores e outros fatores de transcrição (NILSSON et al., 2001).

$O$ estrógeno atua via 2 tipos de receptores, o ERa e o ERß e tem influência direta na proliferação, diferenciação e desenvolvimento folicular (DRUMMOND; FINDLAY, 1999).

Os dois subtipos de receptores de estrógeno (ERa e ER $\beta$ ) são codificados por genes diferentes. ERa e ERß têm grande homologia na região de ligação ao DNA (DBD), mas diferem na região de ligação ao ligante (LBD) C-terminal e na região de domínio de transativação (AF-1) N-terminal (BROSENS et al., 2004).

Os mecanismos específicos que participam da atuação do estrógeno e de seus receptores nos ovários precisam ser melhor elucidados (RICHARDS, 2001).

Uma das ferramentas utilizadas para melhorar a compreensão da função de receptores hormonais é a produção de animais transgênicos knock-out. Tais animais são produzidos de modo não apresentem expressão do gene de interesse, e assim, não possuam o receptor em nenhuma de suas células. A produção de camundongas knock-out para os genes ERa (ERaKO) e ERß (ERßKO) permitiu definir a ação do estrógeno na foliculogênese de forma mais precisa. Camundongas ERaKO são acíclicas, inférteis e possuem ovários hiperêmicos e desprovidos de corpo lúteo (COUSE; KORACH, 1999a). Camundongas ERßKO têm ovários pequenos, desenvolvimento folicular deficiente e fertilidade comprometida, além de número reduzido de corpos lúteos (KREGE et al., 1998).

O conhecimento da distribuição celular dos receptores de estrógeno ERa e ERß é importante para a melhor compreensão da ação do estrógeno no ovário. Os modelos knock-out mostraram que o estrógeno é imprescindível para a foliculogênese adequada até o estádio antral (BRITT; FINDLAY, 2002).

Se os receptores ERa e ER $\beta$ estiverem presentes no mesmo tipo celular, eles podem sofrer homo ou heterodimerização, sendo a última provavelmente a mais 
comum (DRUMMOND e FINDLAY, 1999). Se os receptores ERa e Erß estiverem em diferentes tipos celulares e formarem apenas homodímeros nessas células, uma ação moduladora entre os 2 receptores não será possível, assim fatores parácrinos poderiam estar envolvidos (BRITT e FINDLAY, 2002).

Foram identificados os dois subtipos de receptores estrogênicos (ER) ER $\alpha$ e ER $\beta$ em cães. A expressão de ambos foi identificada no hipotálamo, hipófise e ovários de cadelas nas diferentes fases do ciclo estral. A expressão de $E R \alpha$ apresentou correlação positiva com os níveis plasmáticos de estrógeno, enquanto ER $\beta$ correlacionou-se positivamente com os níveis plasmáticos de progesterona (HATOYA et al., 2003).

$\mathrm{Na}$ cadela, o aumento dos níveis séricos de estrógeno está associado ao aumento no número de ER e PR no endométrio, enquanto elevados níveis de progesterona estão associados à diminuição da população de ambos receptores (JOHNSTON et al; 1985). Tal fenômeno foi confirmado no estudo de GalabovaKovacs et al. (2004), no qual o mesmo efeito foi observado em células endometriais de cadela, cultivadas in vitro após a suplementação com estrógeno e progesterona.

Foi descrita a presença de receptores de esteróides em oócitos de diversas espécies. Oócitos de hamster expressaram tanto ERa quanto ERß (YANG et al., 2004). Pepe et al. (2002) relataram imunorreatividade ao ER $\beta$ em oócitos de babuínos. Expressão gênica de receptores de estrógeno foi observada em camundongas por Wu et al. (1992). O mesmo grupo relatou expressão gênica dos mesmos receptores em oócitos humanos (WU et al., 1993). Não há, até o presente momento, nenhuma descrição da expressão de receptores de estrógeno em oócitos na espécie canina.

A progesterona é um hormônio esteróide sintetizado no ovário, os níveis de progesterona secretados dependem do nível de estímulo por gonadotrofinas e do estado fisiológico do ovário. Além das células da granulosa, células da teca, do estroma ovariano e do corpo lúteo secretam progesterona (DULEBA et al., 1999).

Uma vez secretada pelo ovário, além de exercer ação local, a progesterona atua no eixo hipotálamo-hipófise, regulando a secreção de gonadotrofinas; na glândula mamária, estimulando seu desenvolvimento e no útero (PELUSO, 2006).

Pelo fato da progesterona regular todos esses processos fisiológicos reprodutivos, muitas pesquisas têm objetivado estudar o mecanismo pelo qual a progesterona 
exerce sua ação nesses tecidos.

A progesterona é conhecida por influenciar o crescimento folicular, a ovulação e a luteinização. Estudos in vitro demonstram que a progesterona exerce feed-back positivo sobre a secreção de progesterona pelas células do cumulus e exerce feedback negativo sobre a secreção de estrógeno pelas mesmas células (SCHREIBER et al., 1980).

Peluso (2006) relatou que os receptores de progesterona (PR) são expressos apenas em células da granulosa após exposição prévia à gonadotrofinas (LH).

Um estudo com camundongas knock-out para o gene PR concluiu que o PR é necessário para ocorrer a ovulação. Comundongas knock-out para o gene PR sofreram desenvolvimento folicular normal, porém a ovulação não ocorreu (LYDON et al., 2006).

Bayaa et al. (2000) relataram a presença de PR muito semelhante ao receptor encontrado em mamíferos, em anfíbios da espécie Xenopus laevis. Nesse experimento foi observada a quebra da vesícula germinativa induzida pela progesterona. A superexpressão de PR aumentou a responsividade dos oócitos à progesterona.

Revelli et al. (1996) demonstraram não haver expressão de RNAm de PR em oócitos humanos. Até o presente momento não foi relatada a presença de PR em oócitos de mamíferos.

Receptores de progesterona (PR) foram identificados por imunohistoquímica em diversos tipos de células ovarianas em cadelas nas diferentes fases do ciclo estral. Embora nas células da granulosa tenha sido evidenciada a presença de PR, não foram identificados PR por este método em oócitos (VERMEIRSCH et al., 2001). 


\section{MATERIAL E MÉTODOS}

\subsection{Obtenção do material biológico}

Foram utilizados ovários de 38 cadelas hígidas, entre o início da puberdade e 8 anos de idade, em diferentes fases do ciclo estral, submetidas a ováriohisterectomia (OHE) pelo Serviço de Obstetrícia e Ginecologia do Hospital Veterinário da Faculdade de Medicina Veterinária e Zootecnia da Universidade de São Paulo. Os ovários foram imediatamente transportados ao laboratório em solução fisiológica $\left(\mathrm{NaCl} 0,9 \%\right.$ ) a $7^{\circ} \mathrm{C}$ para minimizar a degradação dos RNAs e inibir a atuação de fatores de transcrição nos oócitos e nas células do cumulus após a colheita dos ovários.

\subsection{Determinação da fase do ciclo estral}

Os animais foram submetidos a avaliação pré-cirúrgica imediata na qual foram realizadas colpocitologia e colposcopia, que auxiliaram na determinação da fase do ciclo estral (quadro 1). Neste momento foi realizada colheita de $5 \mathrm{ml}$ de sangue das veias cefálica ou jugular, sendo acondicionado em frasco sem anti-coagulante. Cada amostra foi centrifugada a $850 \mathrm{~g}$ por 10 minutos para separação do soro, que foi acondicionado em criotubo e conservado a $-20^{\circ} \mathrm{C}$. Os níveis séricos de estrógeno e progesterona foram aferidos pela técnica de radioimunoensaio (kit de progesterona Coat-a-Count-DPC®, Los Angeles, CA, USA; kit de estradiol DSL-39100®, Webster, TX, USA). As análises foram realizadas em duplicata.

Os níveis de progesterona auxiliaram na determinação da fase do ciclo estral, conforme mostra a quadro 1 (OLSON et al., 1984; CONCANNON et al., 1989; TANI et al., 1997; HEWITT et al., 1998). 
Quadro 1 - Comparação entre citologia vaginal, nível sérico de progesterona e vaginoscopia nas diferentes fases do ciclo estral em cadelas - São Paulo - 2007

\begin{tabular}{|c|c|c|c|}
\hline FASE & Colpocitologia & Progesterona & Colposcopia \\
\hline Proestro & $\begin{array}{c}\text { células parabasais, } \\
\text { intermediárias, superficiais } \\
\text { nucleadas e hemácias }\end{array}$ & $<2,0 \mathrm{ng} / \mathrm{ml}$ & $\begin{array}{l}\text { mucosa rosada e } \\
\text { edemaciada, pregas } \\
\text { longitudinais primárias }\end{array}$ \\
\hline Estro & $\begin{array}{l}\text { predomínio de células } \\
\text { superficiais queratinizadas } \\
\text { com núcleo picnótico ou } \\
\text { anucleadas (>90 \%) }\end{array}$ & 2 a $20 \mathrm{ng} / \mathrm{ml}$ & $\begin{array}{c}\text { mucosa com maior } \\
\text { palidez, edemaciação } \\
\text { reduzida e pregas } \\
\text { primárias e secundárias }\end{array}$ \\
\hline Diestro & $\begin{array}{c}\text { células parabasais, } \\
\text { intermediárias, de metaestro } \\
\text { e neutrófilos }\end{array}$ & $>1,5 \mathrm{ng} / \mathrm{ml}$ & $\begin{array}{l}\text { mucosa pálida com } \\
\text { pregas longitudinais } \\
\text { abundantes (roseta) }\end{array}$ \\
\hline Anestro & $\begin{array}{c}\text { poucas células parabasais e } \\
\text { basais, além de citólise }\end{array}$ & $<2 \mathrm{ng} / \mathrm{ml}$ & $\begin{array}{c}\text { mucosa pálida com } \\
\text { pregas longitudinais e } \\
\text { flacidez }\end{array}$ \\
\hline
\end{tabular}




\subsection{Recuperação dos oócitos e células do cumulus}

Os complexos cumulus-oócitos (COCs) foram recuperados por fatiamento fino dos ovários com bisturi, em placa de Petri contendo solução salina fosfatada (PBS) adicionada de $10 \%$ de soro fetal bovino (FCS) a $7^{\circ} \mathrm{C}$ (modificado de VANNUCCHI, 2003). A temperatura do laboratório foi mantida a aproximadamente $15^{\circ} \mathrm{C}$ por condicionador de ar.

Os oócitos foram colocados em placa de Petri de $35 \mathrm{~mm}$ com PBS $+10 \%$ FCS a $7^{\circ} \mathrm{C}$ sobre gelo para manutenção da temperatura. Os oócitos foram desnudados mecanicamente com micropipeta fina (diâmetro aproximado do oócito) em grupos de 5 por gota de $30 \mu \mathrm{IBS}+10 \% \mathrm{FCS}$ a $7^{\circ} \mathrm{C}$. Quando ocorria ruptura da membrana plasmática do oócito, a gota com as células do cumulus era desprezada para evitar contaminação das células do cumulus com RNA do oócito rompido. Após o desnudamento, os oócitos foram colocados em uma gota de $500 \mu \mathrm{l}$ da mesma solução e à mesma temperatura e, posteriormente, acondicionados em criotubos e congelados a $-80^{\circ} \mathrm{C}$ até $o$ isolamento do RNA. As gotas, nas quais os oócitos foram desnudados, foram aspiradas e a solução com as células do cumulus foi colocada em tubo de microcentrífuga de $0,5 \mathrm{ml}$ e centrifugada a $1000 \mathrm{~g}$ por 10 minutos, sendo o sobrenadante desprezado e o sedimento com as células do cumulus congelado a $80^{\circ} \mathrm{C}$ até o isolamento do RNA.

A relação dos animais, os níveis séricos de estrógeno e progesterona e o número de oócitos recuperados e denudados está na tabela 1. A relação das amostras de células do cumulus está descrita na tabela 2. A relação dos oócitos está descrita na tabela 3. 
Tabela 1 - Relação dos animais, níveis séricos de estradiol e progesterona (CV\% $\uparrow=7,50 \%, \quad C V \downarrow=0,69 \%)$, número de oócitos recolhidos e denudados. (-) Dosagem não realizada - São Paulo - 2007

\begin{tabular}{|c|c|c|c|c|}
\hline Animais & $\begin{array}{c}\text { Progesterona } \\
(\mathrm{ng} / \mathrm{ml})\end{array}$ & $\begin{array}{c}\text { Estradiol } \\
(\mathrm{ng} / \mathrm{ml})\end{array}$ & Ooócitos recuperados & Oócitos denudados \\
\hline 1 & 0,11 & 9,64 & 160 & 50 \\
\hline 2 & 1,09 & 6,84 & 55 & 25 \\
\hline 3 & 1,74 & 9,73 & 115 & 53 \\
\hline 4 & 2,71 & 10,36 & 80 & 34 \\
\hline 5 & 3,56 & 7,11 & 37 & 5 \\
\hline 6 & 0,38 & 86,87 & 32 & 12 \\
\hline 7 & 11,48 & 11,86 & 25 & 12 \\
\hline 8 & 4,53 & - & 91 & 26 \\
\hline 9 & 0,1 & 8,14 & 48 & 18 \\
\hline 11 & 0,13 & 8,2 & 89 & 35 \\
\hline 12 & 12,14 & 8,9 & 261 & 70 \\
\hline 13 & 13,47 & 11,14 & 21 & 11 \\
\hline 15 & 18,12 & 10,93 & 78 & 33 \\
\hline 16 & 1,72 & 7,28 & 18 & 9 \\
\hline 17 & 0,58 & 14,02 & 52 & 20 \\
\hline 18 & 0,12 & 14,64 & 174 & 50 \\
\hline 21 & 20 & 12,75 & 43 & 17 \\
\hline 22 & 0,63 & 18,35 & 73 & 40 \\
\hline 23 & 18,79 & - & 19 & 9 \\
\hline 24 & 26,26 & - & 72 & 41 \\
\hline 25 & 3,7 & - & 160 & 98 \\
\hline 26 & 6,61 & - & 510 & 113 \\
\hline 27 & 5,1 & 48,05 & 111 & 48 \\
\hline 28 & 0,16 & - & 156 & 53 \\
\hline 29 & 3,98 & 10,43 & 96 & 50 \\
\hline 30 & 28,06 & 9,61 & 237 & 50 \\
\hline 31 & 4,06 & 11,71 & 242 & 75 \\
\hline 32 & 2,26 & 5,79 & 89 & 35 \\
\hline 33 & 0,62 & - & 254 & 51 \\
\hline 34 & 3,34 & 9,94 & 76 & 35 \\
\hline 35 & 16,57 & 8,75 & 23 & 14 \\
\hline 36 & 15,28 & - & 48 & 14 \\
\hline 37 & 1,45 & - & 50 & 14 \\
\hline 38 & 0,07 & - & 102 & 36 \\
\hline
\end{tabular}


Tabela 2 - Amostras de células do cumulus segundo a fase do ciclo estral e as dosagens séricas de estradiol e progesterona.(-) Dosagem não realizada - São Paulo - 2007

\begin{tabular}{|c|c|c|c|}
\hline \multicolumn{4}{|c|}{ CUMULUS OOPHORUS } \\
\hline Fase do ciclo estral & Amostras & Estrógeno (ng/ml) & Progesterona $(\mathrm{ng} / \mathrm{ml})$ \\
\hline \multirow{4}{*}{ PROESTRO } & 6 & 86,87 & 0,38 \\
\hline & 14 & 30,85 & 0,7 \\
\hline & 18 & 14,64 & 0,12 \\
\hline & 20 & 9,64 & 0,11 \\
\hline \multirow{7}{*}{ ESTRO } & 7 & 11,86 & 11,48 \\
\hline & 8 & - & 4,53 \\
\hline & 12 & 8,9 & 12,14 \\
\hline & 13 & 11,14 & 13,47 \\
\hline & 15 & 10,93 & 18,12 \\
\hline & 19 & 11,03 & 1,88 \\
\hline & 21 & 12,75 & 20,0 \\
\hline \multirow{5}{*}{ DIESTRO } & 1 & 11,06 & 6,14 \\
\hline & 4 & 10,36 & 2,71 \\
\hline & 5 & 7,11 & 3,56 \\
\hline & 10 & 7,79 & 1,24 \\
\hline & 16 & 7,28 & 1,72 \\
\hline \multirow{5}{*}{ ANESTRO } & 2 & 6,84 & 1,09 \\
\hline & 3 & 9,73 & 1,74 \\
\hline & 9 & 8,14 & 0,1 \\
\hline & 11 & 8,2 & 0,13 \\
\hline & 17 & 14,02 & 0,58 \\
\hline
\end{tabular}


Tabela 3 - Amostras de células do oócitos segundo a fase do ciclo estral e as dosagens séricas de estradiol e progesterona.(-) Dosagem não realizada - São Paulo - 2007

\begin{tabular}{|c|c|c|}
\hline $\begin{array}{c}\text { Fase do ciclo } \\
\text { estral }\end{array}$ & Amostra & Animais \\
\hline \multirow{3}{*}{ PROESTRO } & $A$ & 22,6 \\
\hline & B & 1 \\
\hline & C & 18 \\
\hline \multirow{8}{*}{ ESTRO } & $D$ & 23,24 \\
\hline & $E$ & 25 \\
\hline & $\mathrm{F}$ & 26 \\
\hline & G & 27 \\
\hline & $\mathrm{H}$ & 12 \\
\hline & $\mathrm{R}$ & 8,34 \\
\hline & $S$ & $7,13,35,36$ \\
\hline & $\mathrm{T}$ & 15,21 \\
\hline \multirow{5}{*}{ DIESTRO } & M & 29 \\
\hline & $\mathrm{N}$ & 30 \\
\hline & $\mathrm{O}$ & 31 \\
\hline & $P$ & $5,16,22$ \\
\hline & $U$ & 4,37 \\
\hline \multirow{5}{*}{ ANESTRO } & I & 28 \\
\hline & J & 3 \\
\hline & L & $2,11,17$ \\
\hline & Q & 33 \\
\hline & $\mathrm{V}$ & 9,38 \\
\hline
\end{tabular}




\subsection{Isolamento do RNA total}

Para extração do RNA total foram utilizados os procedimentos descritos abaixo.

3.4.1 Isolamento do RNA total de oócitos e de células do cumulus

O RNA total foi extraído das células do cumulus segundo recomendações do fabricante, empregando o sistema RNeasy ${ }^{\circledR}$ Protect Mini Kit (Qiagen), que se baseia no método do isotiocianato de guanidina. A ressuspensão da amostra foi feita em $16 \mu l$ de água ultrapura (milli-Q®). A extração de RNA total dos oócitos foi realizada pelo método do reagente Trizo|® (Invitrogen), ressuspendendo-se o RNA em volume total de $16 \mu \mathrm{L}$ de água ultrapura. A quantidade de oócitos para para obtenção de RNA total para os experimentos de expressão gênica foi de 50 oócitos (Buratini Junior, comunicação pessoal, 2005).

\subsubsection{Isolamento do RNA total de ovários}

O isolamento de RNA total de ovário de cadelas foi realizado para validação dos oligonucleotídeos iniciadores e padronização e calibração das reações de PCR. Foi retirado um fragmento de aproximadamente $100 \mathrm{~g}$ de ovário previamente criopreservadoo a $-80^{\circ} \mathrm{C}$ que foi envolvido por várias camadas de papel alumínio e colocado em nitrogênio líquido por 30 segundos. O material foi colocado sobre uma bancada e macerado. O RNA total foi extraído do macerado de ovário, utilizando-se o reagente Trizol $\circledast$ (Invitrogen), seguindo orientação do fabricante. A quantidade de RNA total foi de $1 \mu \mathrm{g}$ por reação de síntese de cDNA. A quantificação do RNA total foi feito pelo aparelho "BioPhotometer" (Cat. No. 6131 000.012) fornecido pela Eppendorf $\circledast$, com diluição de 1:50. 


\subsection{Síntese do DNA complementar (cDNA)}

A síntese do cDNA foi realizada, segundo recomendações do fabricante, pela reação de transcriptase reversa, utilizando-se o sistema SuperScript ${ }^{\circledR}$ First-Strand Synthesis for RT-PCR (INVITROGEN) com $8 \mu \mathrm{l}$ de RNA total na presença de Random Hexamers.

\subsection{Reação de amplificação por PCR em tempo real}

As reações de amplificação por PCR em tempo real foram realizadas conforme as descrições abaixo.

3.6.1 Desenho dos oligonucleotídeos iniciadores

Os oligonucleotídeos iniciadores foram sintetizados de acordo com Hatoya et al. (2003) para os genes $18 \mathrm{~S}$ e ERß e de acordo com Papa (comunicação pessoal) ${ }^{2}$, para os genes Era e PR. O gene constitutivo $18 \mathrm{~S}$ foi utilizado como controle endógeno e normalizador da reação. A seqüência dos oligonucleotídeos e tamanho esperado dos fragmentos após a amplificação encontram-se na tabela 4. 
Tabela 4 - Relação das seqüências, tamanho dos fragmentos amplificados, temperaturas e tempos de anelamento dos oligonucleotídeos iniciadores. Informações relativas aos oligonucleotídeos iniciadores PR e ERa foram derivadas do Gene Bank, números de acesso AF177470 an AY533243, respectivamente - São Paulo - 2007

\begin{tabular}{|c|c|c|c|}
\hline OLIGONUCLEOTÍDEOS & Seqüência & $\begin{array}{c}\text { Tamanho } \\
\text { dos } \\
\text { fragmentos }\end{array}$ & $\begin{array}{c}\text { Temperatura de } \\
\text { anelamento }\end{array}$ \\
\hline $18 \mathrm{~S}$ forward & 5' - TGGTTGATCCTGCCAGTAGCA - 3' & \multirow{2}{*}{$96 \mathrm{pb}$} & \multirow{2}{*}{$60^{\circ} \mathrm{C}$} \\
\hline $18 S$ reverse & 5' - ATGAGCCATTCGCAGTTTCACT - 3' & & \\
\hline Era forward & 5' - GGTCTTGGTGTTGGGTGTG -3' & \multirow{2}{*}{$100 \mathrm{pb}$} & \multirow{2}{*}{$59^{\circ} \mathrm{C}$} \\
\hline Era reverse & 5' - GGACATATTCCTCACGCTCC - 3' & & \\
\hline $\operatorname{Er} \beta$ forward & 5' - TTCTATAGCCCTGCTGTGATGAAT - 3' & \multirow{2}{*}{$402 \mathrm{pb}$} & \multirow{2}{*}{$60^{\circ} \mathrm{C}$} \\
\hline Er $\beta$ reverse & 5' - ATTATGTCCTTGAATGCTTCTTTT - 3' & & \\
\hline PR forward & 5' - CAACACCAAACCTGATAC - 3' & \multirow{2}{*}{$173 \mathrm{pb}$} & \multirow{2}{*}{$57,5^{\circ} \mathrm{C}$} \\
\hline PR reverse & 5' - TCCATCCTAGTCCAAACAC - 3' & & \\
\hline
\end{tabular}

3.6.2 Agrupamento dos oócitos para extração de RNA

Buratini Junior (2005) diz que para cada reação foram utilizados 50 oócitos (comunicação pessoal) $^{3}$. Entretanto, não foi possível obter, em grande parte das cadelas, esse número de oócitos denudados. Assim, as cadelas com número insuficiente de oócitos foram agrupadas de acordo sua fase do ciclo estral. Foram utilizados oócitos congelados da mesma cadela quando o número foi 50 ou superior. A relação dos oócitos segundo o agrupamento, bem como o volume para extração de RNA está na tabela 5. 
Tabela 5 - Descrição dos oócitos segundo fase do ciclo estral, agrupamentos, número de oócitos e volume de RNA para síntese de cDNA - São Paulo - 2007

\begin{tabular}{|c|c|c|c|c|}
\hline \multicolumn{5}{|c|}{ oócITOS } \\
\hline Fase do ciclo estral & Amostra & Animais & Número de oócitos & Volume de RNA $(\mu \mathrm{l})$ \\
\hline \multirow{3}{*}{ PROESTRO } & $A$ & 22,6 & 52 & 7,70 \\
\hline & B & 1 & 50 & 8,00 \\
\hline & $\mathrm{C}$ & 18 & 50 & 8,00 \\
\hline \multirow{8}{*}{ ESTRO } & $\mathrm{D}$ & 23,24 & 50 & 8,00 \\
\hline & $E$ & 25 & 98 & 4,08 \\
\hline & $\mathrm{F}$ & 26 & 100 & 4,00 \\
\hline & G & 27 & 50 & 8,00 \\
\hline & $\mathrm{H}$ & 12 & 50 & 8,00 \\
\hline & $\mathrm{R}$ & 8,34 & 61 & 6,56 \\
\hline & $S$ & $7,13,35,36$ & 51 & 7,84 \\
\hline & $T$ & 15,21 & 50 & 8,00 \\
\hline \multirow{5}{*}{ DIESTRO } & M & 29 & 50 & 8,00 \\
\hline & $\mathrm{N}$ & 30 & 50 & 8,00 \\
\hline & $\mathrm{O}$ & 31 & 75 & 5,33 \\
\hline & $\mathrm{P}$ & $5,16,22$ & 50 & 8,00 \\
\hline & $U$ & 4,37 & 50 & 8,00 \\
\hline \multirow{5}{*}{ ANESTRO } & I & 28 & 53 & 7,55 \\
\hline & $\mathrm{J}$ & 3 & 53 & 7,55 \\
\hline & L & $2,11,17$ & 50 & 8,00 \\
\hline & Q & 33 & 51 & 7,84 \\
\hline & $\mathrm{V}$ & 9,38 & 54 & 7,41 \\
\hline
\end{tabular}




\subsubsection{Reação de amplificação}

As reações de PCR em Tempo Real foram padronizadas com material proveniente de ovário macerado de cadela em anestro. O cDNA de ovário foi diluído para se aproximar à quantidade de material presente nas amostras de oócitos e células do cumulus. Foi utilizado o sistema SYBR Green®. O volume dos reagentes das reações de PCR estão descritos no tabela 5 .

A expressão do mRNA foi estimada mediante PCR em tempo real, utilizando o aparelho "7500 Real-Time PCR System" (Cat. No. 4351105) fornecido pela Applied Biosystems. A técnica de PCR em tempo real é sensível e permite a detecção direta dos produtos da PCR durante a fase exponencial da reação, combinando amplificação e detecção em cada ciclo, para isto foi utilizada a técnica de coloração "SYBR Green" para os genes 18S, PR, Era e ER $\beta$. A técnica de coloração pelo "SYBR Green" segue o princípio FRET (Fluorescence Resonance Energy Transfer) e emite sinal de fluorescência quando ligada ao DNA dupla fita.

Para preparação da reação, foi obedecida uma seqüência de preparo das placas para manter a uniformidade máxima dos reagentes presentes em cada tubo. Como foram três genes estudados (PR, Era e ERß) e um gene endógeno (18S) foi estabelecido que haveria uma amostra por linha e um gene a cada duas colunas, respeitando a duplicata.

O mix total foi misturado por linha, iniciando pelo volume de água ultrapura

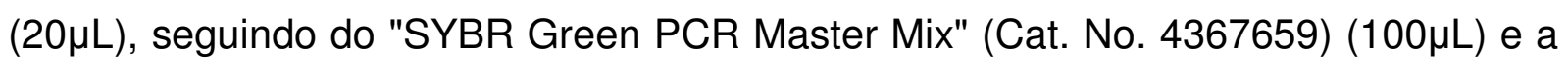
amostra referentes a oito tubos $(8 \mu \mathrm{L})$, após homogeneização, o equivalente às duas reações menos o volume dos oligonucleotídeos $(46 \mu \mathrm{L})$ foi transferido para os tubos da coluna 3 e 5 . Então foi acrescentado o volume de oligonucleotídeos equivalente para duas reações $(2 \mu \mathrm{L}$ do forward a $10 \mu \mathrm{M}$ e $2 \mu \mathrm{L}$ do reverse a $10 \mu \mathrm{M}$ ) a esses tubos das colunas 1 , 3 e 5 . Após nova homogeneização o equivalente a uma reação $(25 \mu \mathrm{L})$ foi transferido para o tubo do lado equivalente. Para cada pipetagem a ponteira foi descartada para evitar variações devido à tensão superficial. Os volumes de reagentes utilizados encontram-se descritos na tabela 6.

O programa inicia com 2 minutos a $50^{\circ} \mathrm{C}$ e segue para 2 minutos a $95^{\circ} \mathrm{C}$ para ativação da enzima DNA polimerase. Então, realizaram-se 45 ciclos com duas etapas, primeira etapa: $95^{\circ} \mathrm{C}$ por 15 segundos, segunda etapa: $60^{\circ} \mathrm{C}$ por 45 
segundos. Posteriormente seguiram-se 15 segundos a $95^{\circ} \mathrm{C}, 60$ segundos a $60^{\circ} \mathrm{C} \mathrm{e}$ 15 segundos a $95^{\circ} \mathrm{C}$ para a curva de dissociação. Pode-se visualizar uma curva de amplificação na figura 2.

Tabela 6 - Descrição dos volumes de reagentes e amostras por tubo para PCR em tempo real - São Paulo - 2007

\begin{tabular}{|c|c|c|c|c|c|c|c|}
\hline Gene & $\begin{array}{c}\text { Master } \\
\text { Mix } \\
\text { Buffer } \\
(\mu L)\end{array}$ & $\begin{array}{l}\text { Água } \\
\text { milli- } \\
Q \circledR \\
(\mu \mathrm{L})\end{array}$ & $\begin{array}{l}\text { ROX } \\
(\mu \mathrm{L})\end{array}$ & 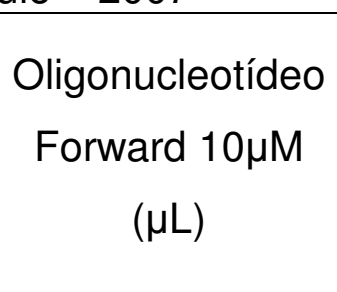 & $\begin{array}{c}\text { Oligonucleotídeo } \\
\text { Reverse } 10 \mu \mathrm{M} \\
(\mu \mathrm{L})\end{array}$ & $\begin{array}{c}\text { Amostra } \\
(\mu \mathrm{L})\end{array}$ & $\begin{array}{l}\text { Vol. } \\
\text { total } \\
(\mu \mathrm{L})\end{array}$ \\
\hline PR & 12,5 & 7,0 & 0,5 & 2,0 & 2,0 & 1,0 & 25 \\
\hline Era & 12,5 & 7,0 & 0,5 & 2,0 & 2,0 & 1,0 & 25 \\
\hline $\mathrm{ER} \beta$ & 12,5 & 7,0 & 0,5 & 2,0 & 2,0 & 1,0 & 25 \\
\hline $18 S$ & 12,5 & 7,0 & 0,5 & 2,0 & 2,0 & 1,0 & 25 \\
\hline
\end{tabular}

\subsection{Análise Estatística}

Para análise da comparação entre a média de oócitos recuperados por fase do ciclo estral e entre as porcentagens das amostras que expressaram os genes de interesse foi utilizado o software "JMP versão 5.1.2" para Windows, pelo teste de análise de variância, com nível de significância de 5\% ( $P=0,05)$.

Para análise dos dados de PCR foram utilizados os critérios a seguir: Para o cálculo da eficiência da reação foi utilizado o software "LinRegPCR", em que o calculo da eficiência é baseado na curva de amplificação individual de cada tubo $(\Delta \mathrm{Rn})$.

Foram estabelecidos os limites inferior e superior ("janela de linearidade") em que as amostras estejam em fase logarítmica, mínimo de 4 pontos incluídos na regressão e com correlação de no mínimo 0,999 . O threshold foi determinado dentro do intervalo delimitado pelos limites superior e inferior da reta de amplificação utilizada pelo "software LinRegPCR" versão 7.0 para o cálculo da eficiência, garantindo assim que os CTs adquiridos encontram-se dentro da reta de eficiência conhecida (Figura 2). 
Utilizando-se o threshold calculado para cada gene, determinou-se os valores dos CTs de cada amostra no programa "7500 System SDS Software" (Figura 3). A quantificação final da expressão relativa dos genes de interesse foi utilizada a comparação dos CTs de acordo com a eficiência individual de cada reação. Posteriormente, cada dado de expressão relativa calibrada por uma amostra de ovário em anestro foi analisado pelo "Software JMP 5.1" (SAS Institute, EUA) pelo teste de análise de variância, com nível de significância de 5\% ( $P=0,05)$.

A comparação entre os níveis séricos de estradiol e progesterona nas diferentes fases do ciclo estral foi realizada ANOVA utilizando PROC GLM do SAS system for Windows. Considerando como variáveis dependentes os níveis séricos de estradiol e progesterona, e as variáveis independentes as fases do ciclo estral. 


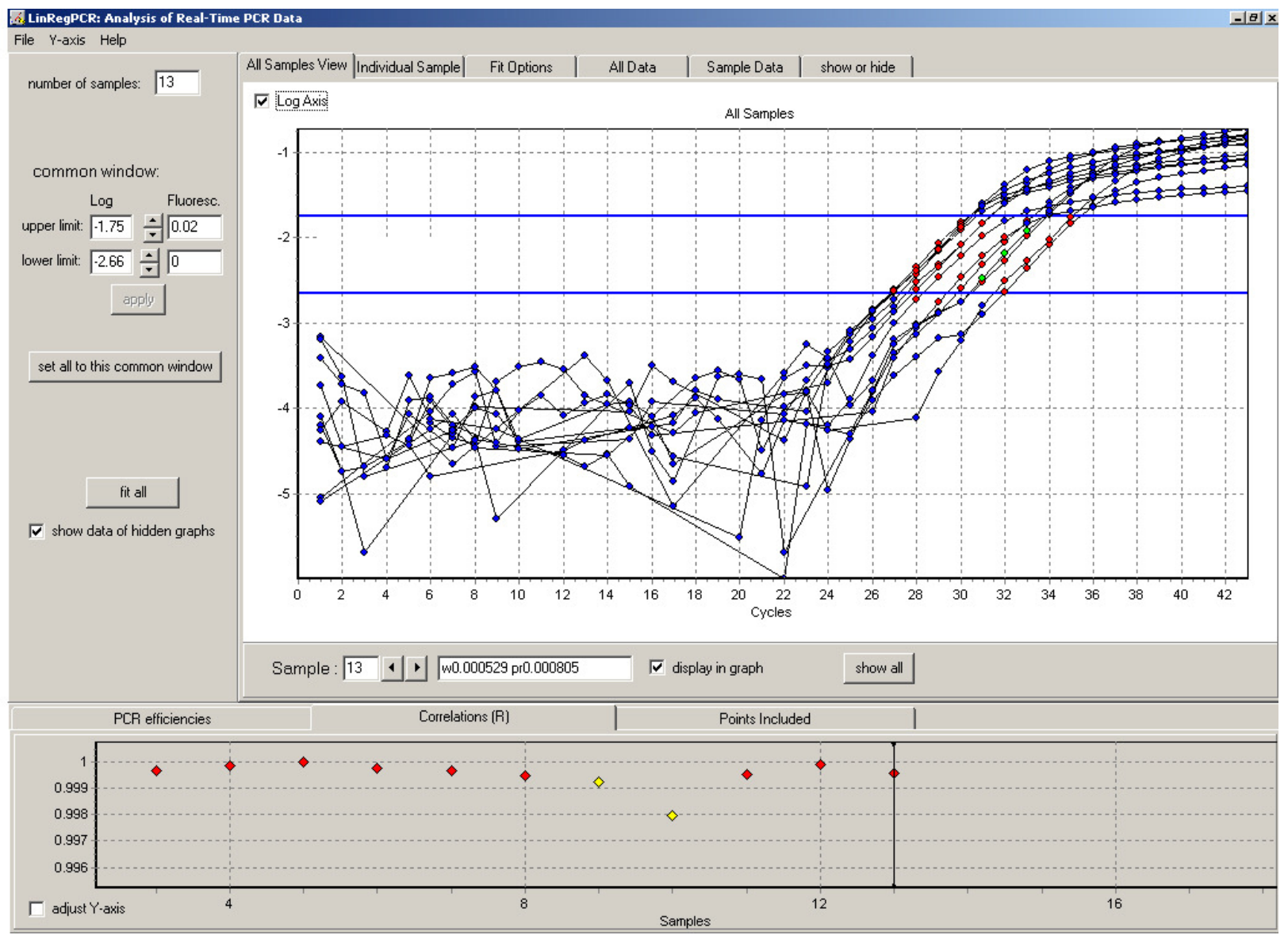

Figura 2 - Exemplo de análise da curva de eficiência para cada poço individual pelo software "LinRegPCR". As linhas azuis do gráfico superior indicam intervalo analisado da curva de amplificação em sua fase exponencial e o gráfico inferior mostra as eficiências calculadas 


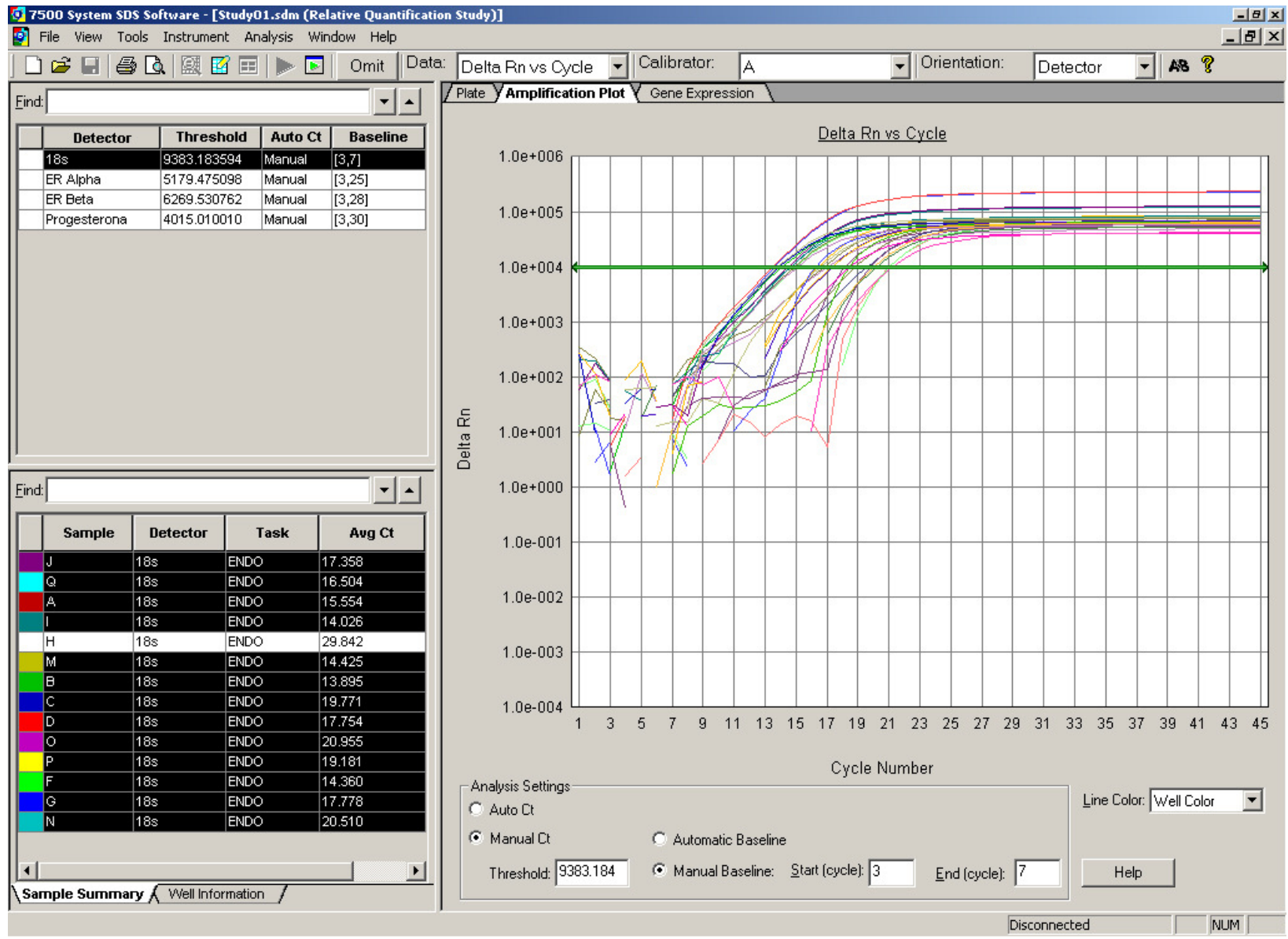

Figura 3 - Exemplo do software "SDS 7500", janela "curva de amplificação". Visualiza-se as curvas de amplificação de diferentes amostra na janela principal, bem como os CTs obtidos na janela inferior esquerda 


\section{RESULTADOS}

Ovários de 38 cadelas foram fatiados para recuperação dos COCs, e um utilizado como normalizador e calibrador das reações de PCR.

\subsection{Média de Oócitos Recuperados}

O número total de oócitos recuperados foi de 3697. Assim, o número médio de oócitos recuperados por animal foi de 97,29. Vale ressaltar que, para o presente estudo, os oócitos não foram pré-selecionados. Entretanto, apenas os oócitos com melhor aspecto, citoplasma homogêneo e maior número de camadas de células mostraram-se aptos a serem denudados. Grande parte dos oócitos tiveram a membrana plasmática rompida durante o processo de denudamento, principalmente os oócitos de qualidade inferior. O número total de oócitos que apresentaram-se íntegros após o denudamento foi de 1256. A média de oócitos recuperados em cada fase do ciclo estral está descrito na tabela 7.

Tabela 7 - Número de oócitos recuperados de acordo com a fase do ciclo estral em cadelas - São Paulo - 2007

\begin{tabular}{cc}
\hline Fase do ciclo estral & Média de oócitos recuperados $(\mathrm{n})$ \\
\hline Proestro & $114,28 \pm 29,67(5)$ \\
Estro & $135,22 \pm 54,22(15)$ \\
Diestro & $99,25 \pm 24,47(9)$ \\
Anestro & $115,5 \pm 33,38(9)$ \\
\hline
\end{tabular}




\subsection{Expressão gênica}

Dentre todos os genes estudados, apenas o 18S (endógeno) foi amplificado em todas as amostras (Figura 4). Todos os genes de interesse foram amplificados em células do cumulus, entretanto, apenas em parte das amostras foi detectada expressão dos genes de interesse. O gráfico 1 evidencia a porcentagem das amostras de células do cumulus que expressaram os genes de interesse nas diferentes fases do ciclo estral.

No gráfico 2 pode-se verificar a porcentagem de oócitos que expressaram os genes de interesse.

A quantificação relativa dos genes de interesse foi realizada tanto em oócitos como em células do cumulus. A análise estatística incluiu apenas as amostras nas quais houve amplificação. A quantificação relativa utilizou como base a amostra de ovário de cadela em anestro. Os resultados foram apresentados em bases logarítmicas, como pode ser visualizado no gráfico 3 para as anostras de células do cumulus e no gráfico 4 para as amostras de oócitos. Não foi observada diferença significativa entre as fases do ciclo estral quanto a expressão de PR, ERa e ERß.

\subsection{Níveis séricos dos hormônios esteróides}

Os níveis séricos de estradiol e progesterona foram comparados entre as diferentes fases do ciclo estral. O gráfico 5 compara os níveis séricos de estradiol entre as diferentes fases do ciclo estral. O gráfico 6 demonstra a mesma comparação realizada com a progesterona. 


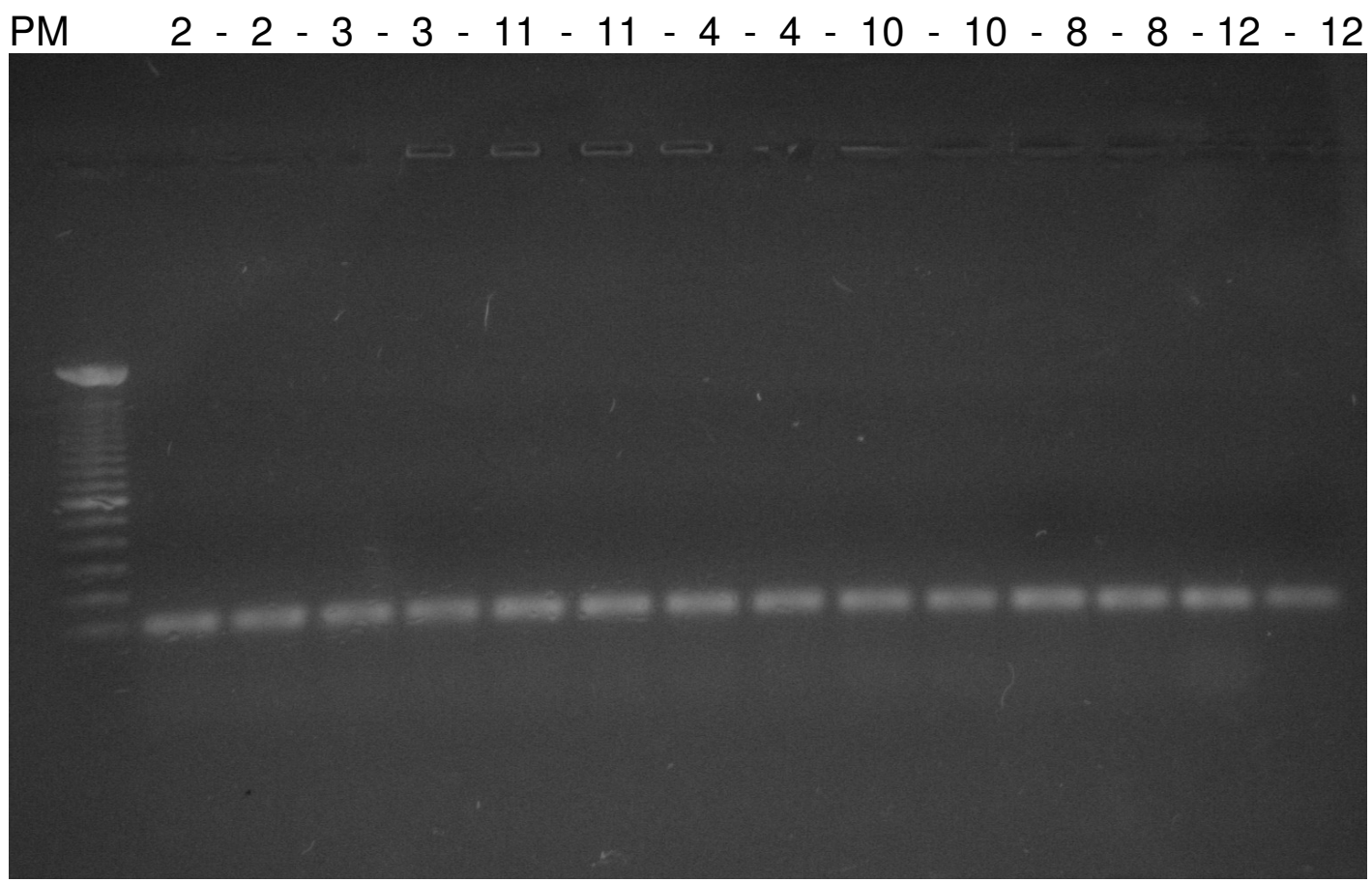

Figura 4 - Eletroforese em gel de agarose em tampão TBE 1x corado com Brometo de Etídeo e visualizado sobre luz ultravioleta dos produtos de PCR do fragmento do gene 18S rRNA (96 bp) PM= peso molecular 100 bp e 2, 3, 11, 4, 10, 8 e 12 = amostras de células do cumulus. Foi realizada eletroforese das duas replicatas submetidas a PCR - São Paulo - 2007 


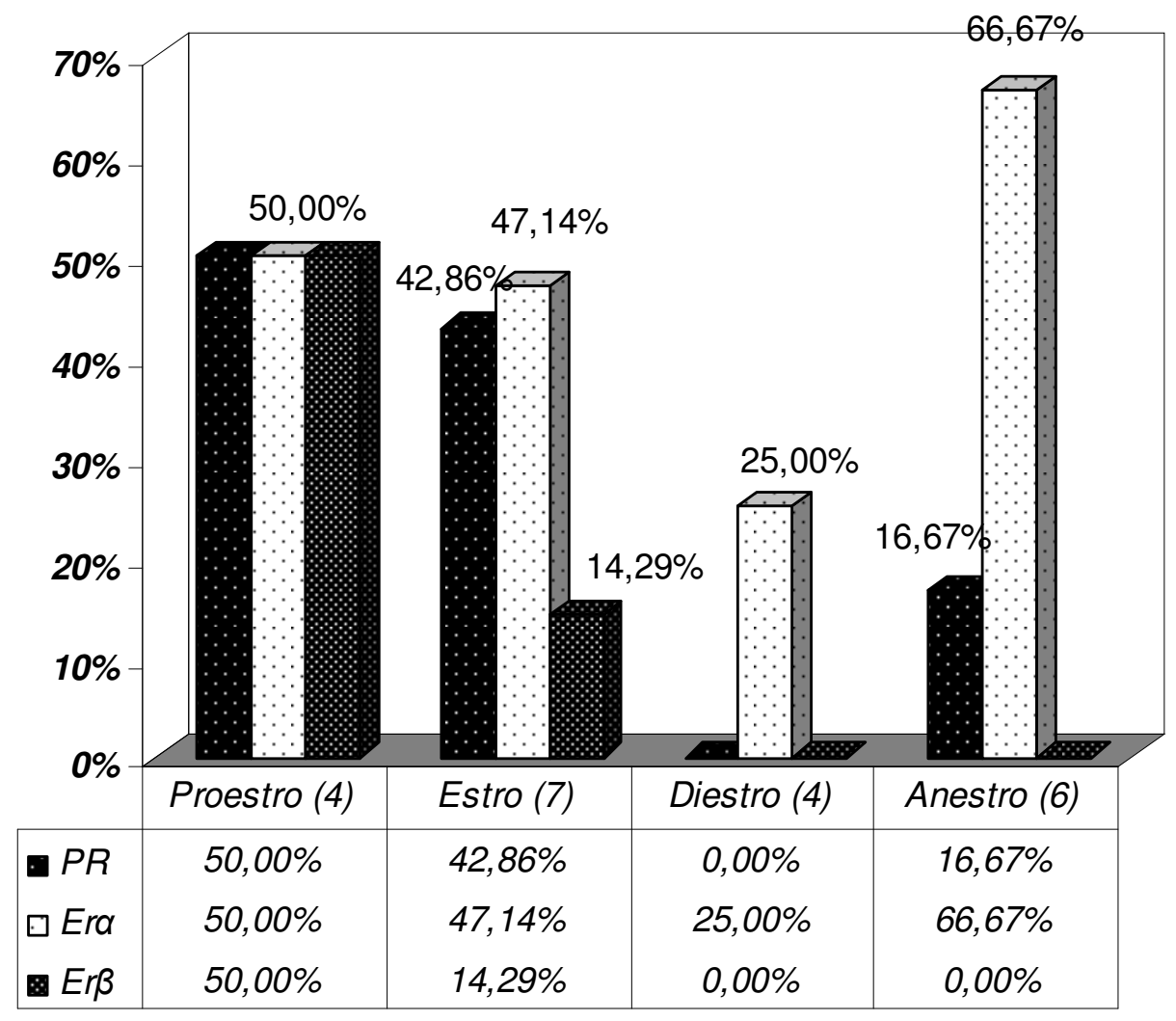

FASE DO CICLO ESTRAL

Diferença não-significativa.

Gráfico 1 - Porcentagem das amostras de células do cumulus que apresentaram expressão dos genes PR, ERa e ER $\beta$, de acordo com as fases do ciclo estral em cadelas - São Paulo - 2007 


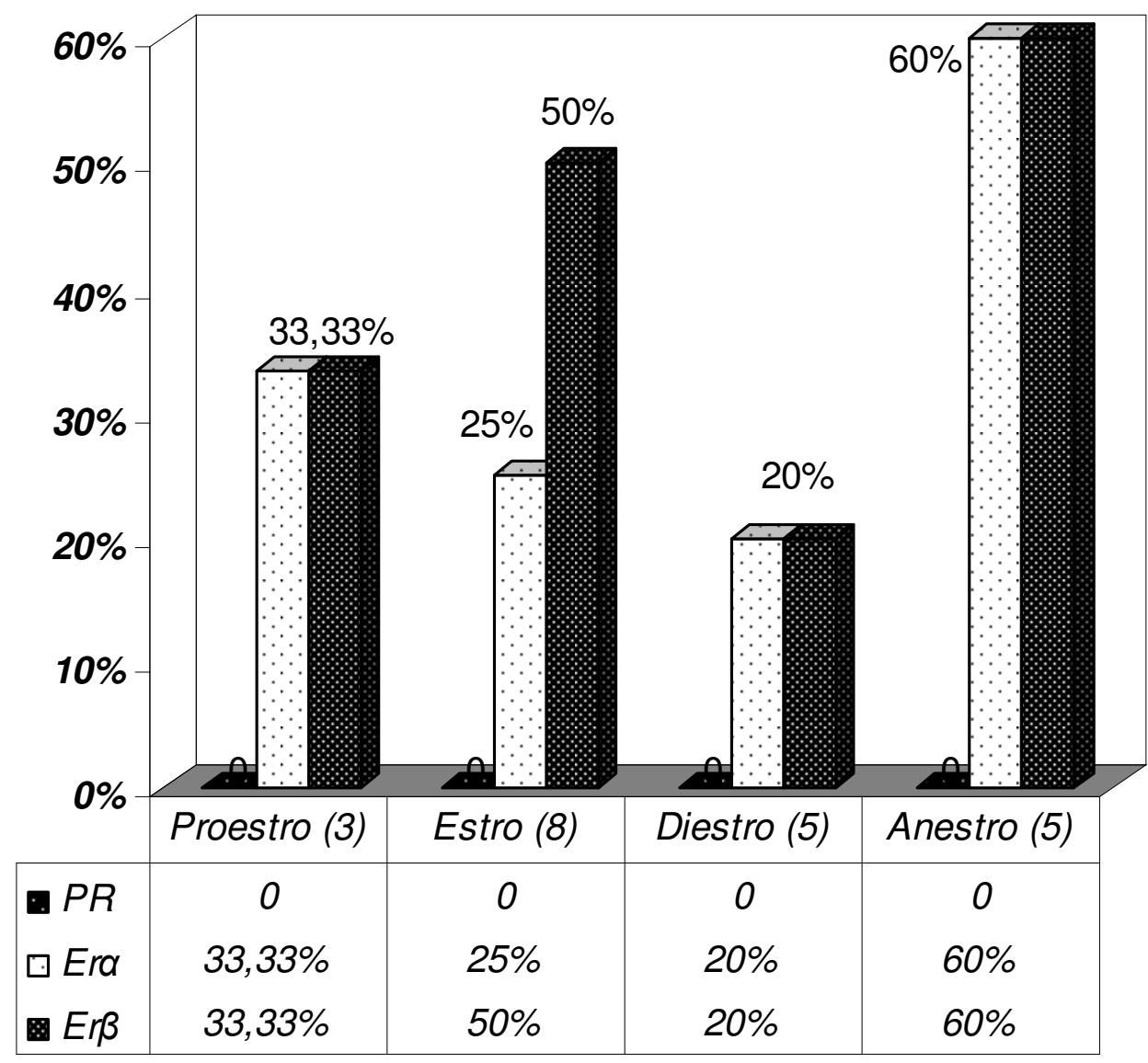

FASE DO CICLO ESTRAL

Diferença não-significativa.

Gráfico 2 - Porcentagem das amostras de oócitos que apresentaram expressão dos genes PR, ERa e ER $\beta$, de acordo com as fases do ciclo estral em cadelas - São Paulo - 2007 


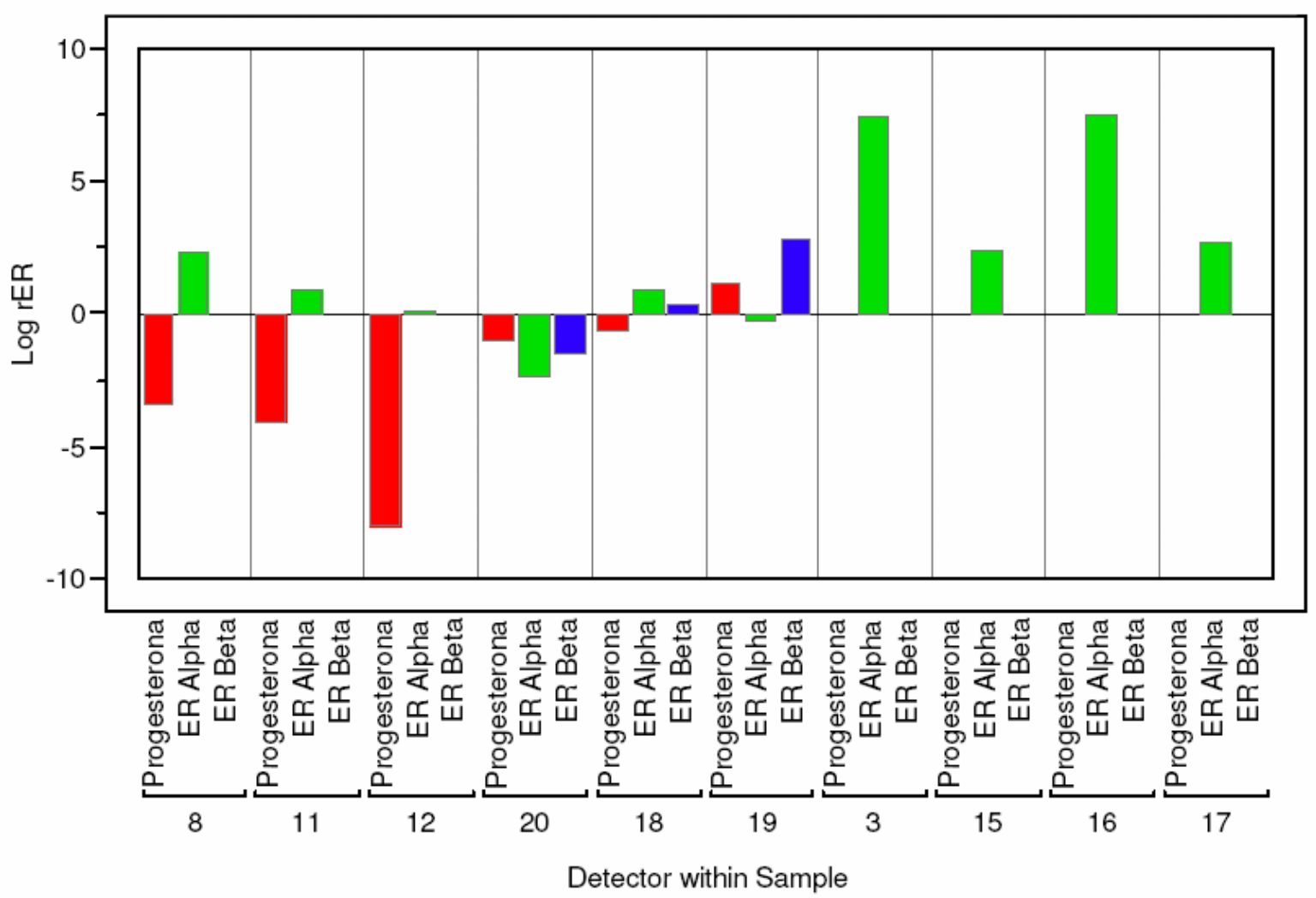

Detector $\square$ Progesterona $\square$ ER Alpha $\square$ ER Beta

Diferença não-significativa.

Gráfico 3 - Quantificação relativa da expressão dos genes PR, ERa e ER $\beta$ em células do cumulus e cadelas. Valores expressos em logaritmo - São Paulo - 2007 


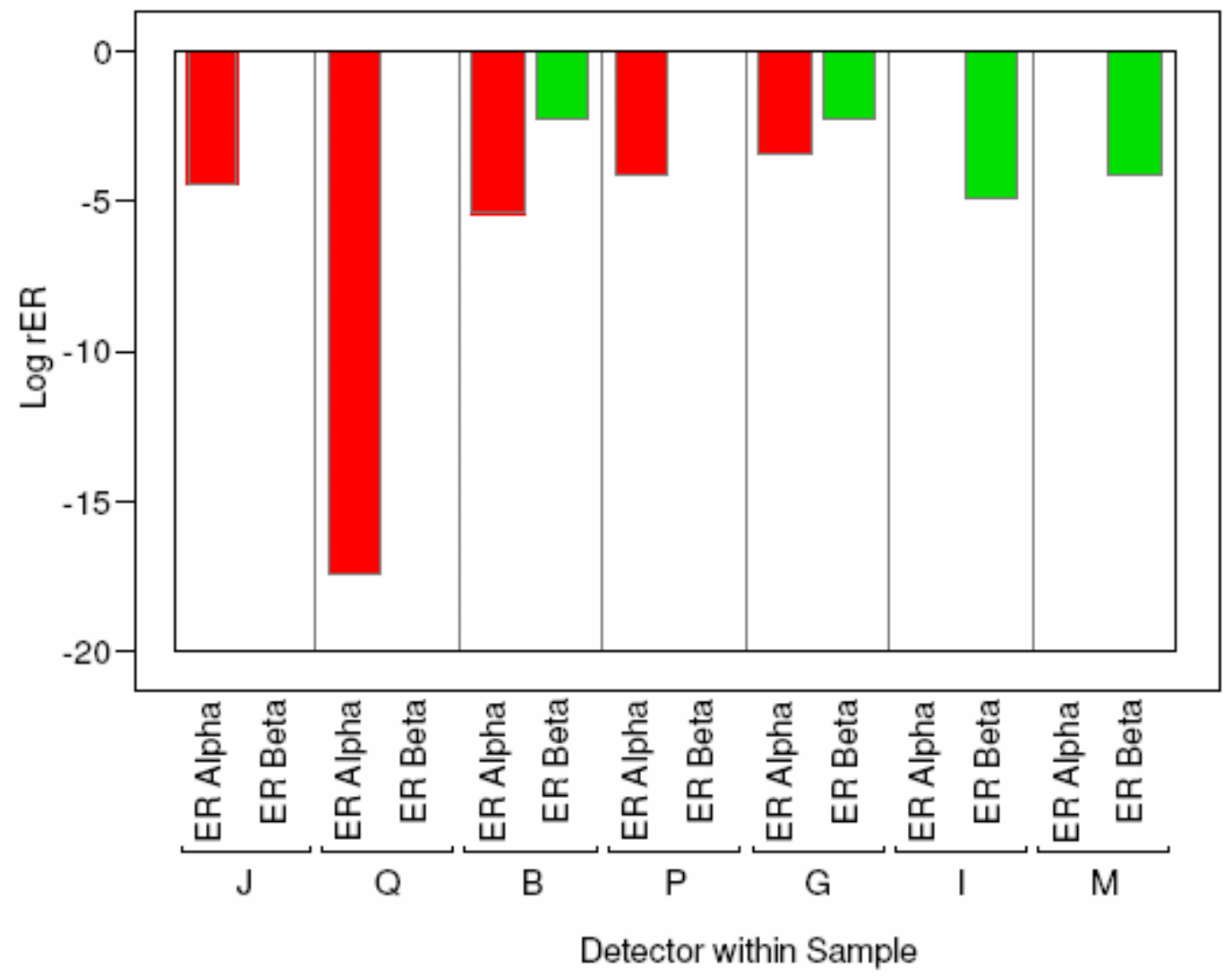

Detector —ER Alpha $\square$ ER Beta

Diferença não-significativa.

Gráfico 4 - Quantificação relativa da expressão dos genes PR, ERa e ER $\beta$ em oócitos em cadelas. Valores expressos em logaritmo - São Paulo - 2007 


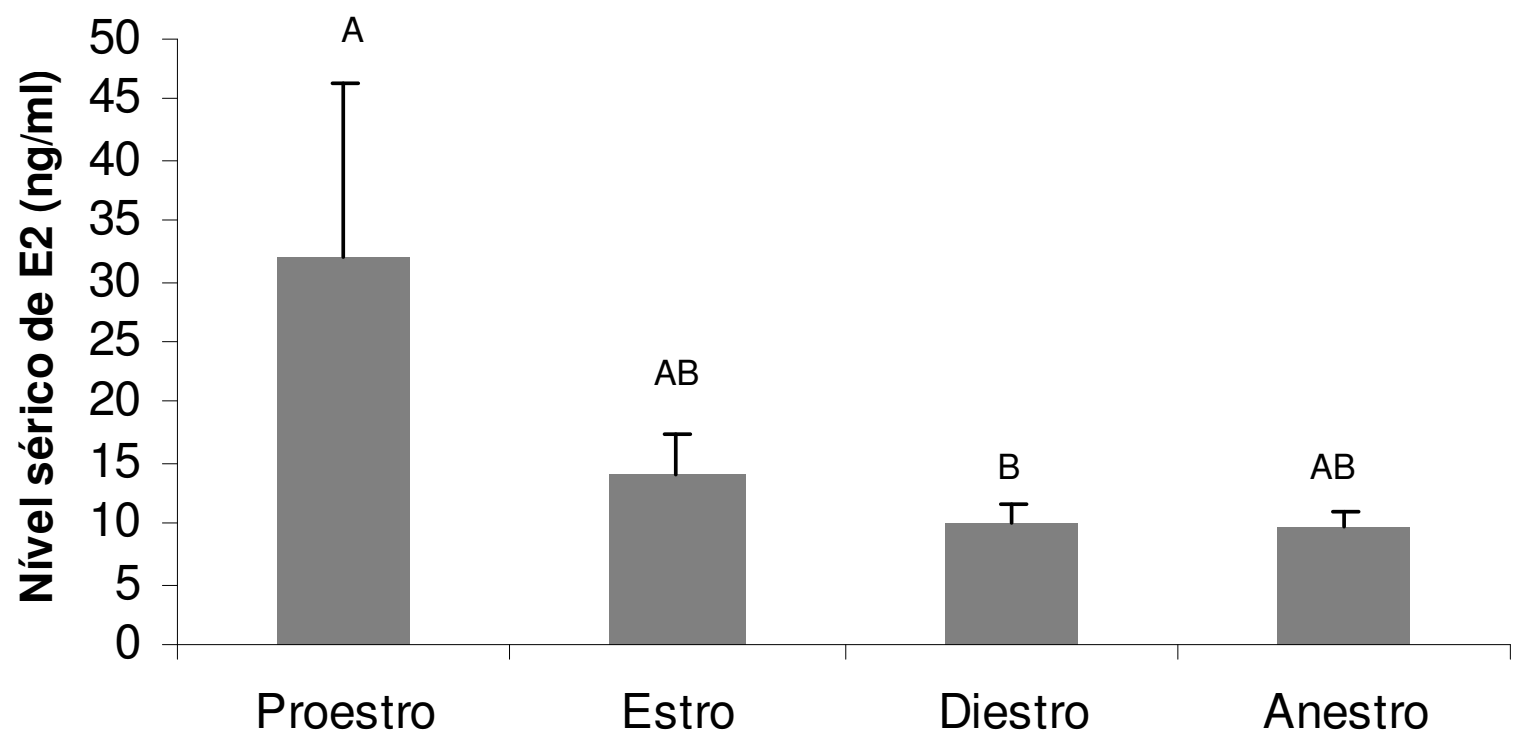

Letras diferentes indicam diferença significativa $(p<0,05)$

Gráfico 5 - Comparação entre os níveis séricos de estradiol e as diferentes fases do ciclo estral em cadelas - São Paulo - 2007 


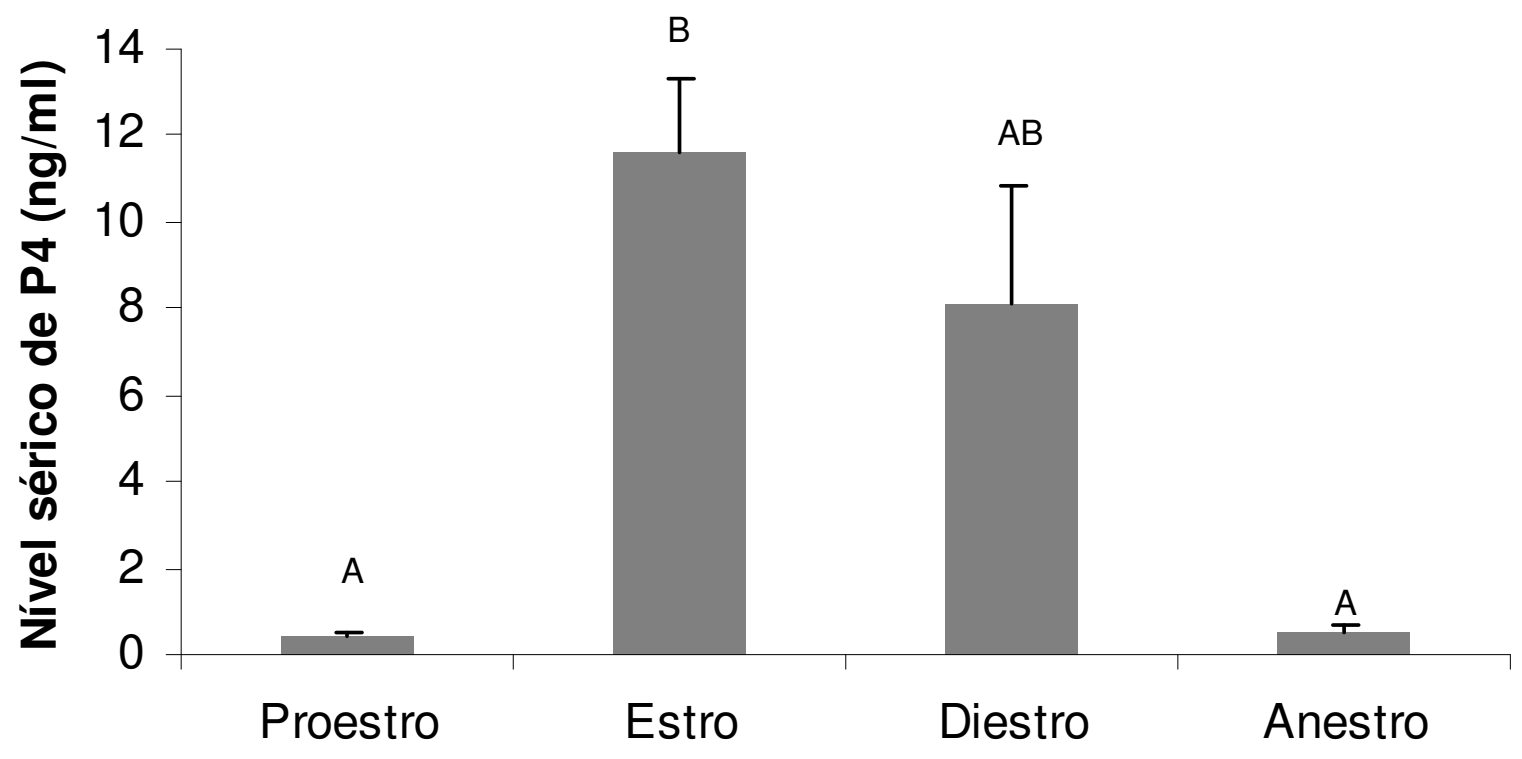

Letras diferentes indicam diferença significativa $(p<0,05)$

Gráfico 6 - Comparação entre os níveis séricos de progesterona e as diferentes fases do ciclo estral em cadelas - São Paulo - 2007 


\section{DISCUSSÃO}

A importância das biotécnicas da reprodução é inegável. A cada dia novas técnicas são desenvolvidas na área de reprodução animal e, com isso, maiores conhecimentos são obtidos acerca dos mecanismos que envolvem a fisiologia reprodutiva das diferentes espécies. As biotécnicas apresentam grande importância social tanto na otimização da produção animal, quanto no desenvolvimento de métodos contraceptivos mais seguros e acessíveis, que colaborariam para a solução de um grave problema que afeta hoje os grandes centros urbanos. Os benefícios proporcionados pela biotecnologia são inúmeros, mas estudos nesta área podem auxiliar no desenvolvimento de programas de preservação de espécies ameaçadas de extinção. Neste cenário o cão tem papel fundamental, já que é utilizado como modelo experimental, estabelecendo referências fisiológicas que podem ser extrapoladas para canídeos selvagens.

O desenvolvimento da biotecnologia da reprodução na espécie canina, apesar da citada importância, está muito aquém do alcançado em espécies de produção. Técnicas como a transferência de embriões (TE), a clonagem por transferência nuclear (TN) e a transgenia necessitam do estabelecimento da produção in vitro (PIV) de embriões de forma viável e consistente. A PIV em cães apresenta resultados insatisfatórios e inconstantes, sendo a maturação in vitro (MIV) de oócitos o maior entrave a ser superado. O sucesso na MIV se dará ao conseguir mimetizar as condições e estímulos aos quais o oócito é submetido durante a maturação in vivo. Muitos grupos têm buscado desenvolver a MIV, alterando protocolos já estabelecidos para outras espécies, porém com resultados insatisfatórios. Haja vista que em cães, os índices de oócitos que atingem MII estão em torno de $20 \%$ (FARSTAD, 2000b). As biotécnicas reprodutivas só atingirão os resultados esperados quando houver conhecimento profundo dos padrões endócrinos e fisiológicos envolvidos no desenvolvimento folicular. A cadela apresenta fisiologia reprodutiva peculiar e muitas são as lacunas acerca dos mecanismos envolvidos no processo de desenvolvimento folicular e maturação oocitária. A espécie canina carece de estudos que objetivem esclarecer as bases fisiológicas da reprodução da espécie.

Com o intuito de melhorar os índices de MIV, suplementações com fatores de 
crescimento, proteínas, anti-oxidantes, soros e hormônios nos meios MIV têm sido testadas. A suplementação do meio MIV com hormônios esteróides e com soro de cadela em estro, que é rico em hormônios esteróides, mostrou-se benéfica por diversos autores. Willingham-Rocky et al. (2003) relataram efeito benéfico da suplementação com progesterona. A suplementação com soro de cadela em estro é benéfica para a MIV (NICKSON et al., 1993; OTOI et al., 1999), Vannuchi (2003) demonstrou que a progesterona, associada ou não ao estrógeno, apresentou efeito positivo na MIV em cadelas em anestro. Luvoni et al. (2001), ao contrário da fase folicular, mostraram não haver junções gap permeáveis em COCs de cadelas em anestro. Observaram também correlação positiva entre a presença das junções gap permeáveis e a competência meiótica em COCs de cadelas no final do proestro. Assim, a atuação dos hormônios esteróides parece ocorrer diretamente sobre o oócito, haja vista a ausência das junções gap, impedindo as "trocas de informações" entre os oócitos e as células do cumulus.

Os resultados da comparação entre os níveis séricos de estradiol e a fase do ciclo estral evidenciaram haver diferença apenas entre as fases de diestro e proestro. Hatoya et al. (2003) por outro lado, além de verificarem diferença entre proestro e diestro, relataram diferença entre o estro e o diestro. Curiosamente, esses autores obtiveram praticamente o mesmo nível sérico médio entre as fases de proestro e estro. Fisiologicamente, entretanto, a fase de proestro é marcada por altos níveis de estradiol que decrescem à medida que o estro se aproxima.

Quanto aos níveis séricos de progesterona, a fase de estro diferiu tanto do proestro como do anestro. O que também está de acordo com a fisiologia endócrina do ciclo estral, em que os níveis séricos de progesterona aumentam sensivelmente na fase final do proestro, momento no qual ocorre luteinização pré-ovulatória nos folículos. Os níveis de progesterona atingem seus valores máximos durante 0 diestro, momento em que os corpos lúteos assumem o papel principal na síntese do hormônio esteróide.

O presente trabalho objetivou verificar a presença de receptores de estrógeno (ERa e ERß) e progesterona (PR) tanto em oócitos como em células do cumulus de cadelas nas diferentes fases do ciclo estral. Com isso, almejamos fornecer maiores bases fisiológicas e, assim, colaborar com o desenvolvimento da biotecnologia da reprodução em cães.

Apesar de não ter sido descrito em outra espécie de mamífero, esperava-se 
encontrar expressão gênica de PR nos oócitos de cadela, uma vez que a progesterona sabidamente influencia no processo de MIV, mesmo em COCs sem comunicação intercelular via junções gap no anestro (Vannucchi, 2003). O fato de não ter sido evidenciada expressão de PR em oócitos de cadela sugere que a progesterona possa atuar no oócito por outra via que não a "via clássica" dos receptores de esteróides. Recentemente têm sido evidenciadas vias de sinalização "não genômica", nas quais os hormônios esteróides exerceriam sua ações mais rapidamente nas células através de ligações aos receptores transmembrana (WIERMAN, 2007). A atuação da progesterona em oócitos provenientes de cadelas em anestro poderia ocorrer por esta via.

Vermeirsch et al. (2001) relataram não haver relação entre os níveis séricos de estradiol, progesterona e testosterona e a proporção de receptores expressos em células foliculares. Apesar de não ter sido detectada diferença significativa entre as expressões de PR, ER $\alpha$ e ERß em relação as fases do ciclo estral em nosso estudo, os resultados mostram que uma amostra de células do cumulus de cadela em anestro final (amostra 3) apresentou relativamente a maior expressão de ERa (Gráfico 3). Curiosamente, dentre as amostras de oócitos, apenas na fase de anestro houve detecção de expressão dos genes ERa e ERß em mais de 50\% das amostras. Entretanto, tanto a amostra que apresentou maior expressão de ERa (amostra G) quanto a amostra que apresentou maior expressão de ERß (amostra B) são provenientes de cadelas em fase folicular de estro e proestro, respectivamente (Gráfico 4).

Nenhuma das amostras de células do cumulus de cadelas em diestro apresentou expressão gênica de PR. Durante o diestro, há altos níveis séricos de progesterona circulantes. Tal resultado está de acordo com Vermeirsch et al. (2001), que relataram que a progesterona sérica apresenta correlação negativa com a expressão de PR em células da granulosa.

Hatoya et al. (2003) relataram que os níveis de RNAm de ERa e ERß aumentam na fase final de anestro. Tal observação sugere que o estrógeno, mediado por ERa e ERß, é vital para os eventos neuroendócrinos associados com a terminação do anestro durante o ciclo ovariano em cães.

Não houve detecção de amplificação dos genes de interesse em grande parte das amostras submetidas a PCR. Tal fato poderia ocorrer caso algumas amostras estivessem degradadas por falha na conservação ou mesmo por erros de técnica. 
Entretanto, em todas as amostras o gene endógeno foi amplificado (Figura 4), o que evidencia a integridade do cDNA submetido a PCR. A não detecção dos genes pode ter ocorrido também no caso dos genes serem expressos em quantidade muito pequena e apesar do equipamento utilizado na PCR em tempo real ser extremamente sensível, poderíamos estar no limite de sensibilidade de detecção da técnica.

Apesar dos contratempos durante o estabelecimento da técnica de PCR, das dificuldades em obter animais nas diferentes fases do ciclo estral, além do número necessário de oócitos para amplificação e do laborioso processamento dos COCs para denudamento completo dos oócitos, o presente estudo foi o primeiro a relatar a expressão gênica dos receptores ERa e ERß em oócitos na espécie canina. $O$ primeira descrição de expressão do gene $E R \beta$ em cães foi feita apenas 2 anos antes do início deste estudo.

Tais estudos acenam para um ótimo cenário num futuro próximo no que se refere às biotécnicas reprodutivas na espécie canina. Muitos grupos de pesquisa que há alguns anos apenas buscavam extrapolar protocolos e técnicas utilizadas em animais de produção para os cães, atualmente empenham-se em pesquisas básicas, que objetivam desvendar os misteriosos caminhos da endocrinologia da reprodução canina. 


\section{CONCLUSÕES}

Com base nos resultados obtidos, pode-se concluir que:

1) Há expressão gênica dos receptores ERa e ERß em oócitos de cadelas nas 4 fases do ciclo estral.

2) Há expressão gênica do receptor de ERa em células do cumulus de cadelas nas 4 fases do ciclo estral. Há expressão gênica do receptor de estrógeno ERß e de progesterona PR em células do cumulus de cadelas nas fases de proestro, estro e anestro.

3) Não houve diferença entre a quantificação relativa de ERa, ERß e PR em células do cumulus e oócitos de cadelas nas diferentes fases do ciclo estral. 


\section{REFERÊNCIAS}

BAYAA, M.; BOOTH, R. A.; SHENG, Y.; LIU, X. J. The classical progesterone receptor mediates Xenopus oocytes maturation through a nongenomic mechanism. PNAS, v. 97, n. 23, p. 12607-12612, 2000. Disponível em: <www.pnas.orgycgiydoiy10.1073ypnas.220302597>. Acesso em: 30 nov. 2006.

BEVERS, M. M.; DIELEMAN, S. J.; VAN DER HURK, R.; IZADYAR, F. Regulation and modulation of oocyte maturation in the bovine. Theriogenology, v. 47, p. 13-22, 1997.

BLONDIN, P.; BOUSQUET, D.; TWAGIRAMUNGU, H.; BARNES, F.; SIRARD, M. A. Manipulation of follicular development to produce developmentally competent bovine oocytes. Biology Reproduction, v. 66, p. 38-43, 2002.

BORDIGNON, E.; NORIN, N.; DUROCHER, J.; BOUSQUET, D.; SMITH, L. C. GnRH improves the recovery rate and the in vitro developmental competence of oocytes obtained by transvaginal follicular aspiration from superstimulated heifers.

Theriogenology, v. 48, p. 291-298, 1997.

BRITT K. L.; FINDLAY J. K. Estrogen actions in the ovary revisited. Journal of Endocrinology, v. 175, p. 269-276, 2002.

BRONSENS, J. J.; TULLET J.; VARSHOCHI R.; LAM E. W. F. Steroid receptor action. Best Practice \& Research Clinical Obstetrics and Gynaecology, v. 18, p. 265-283, 2004.

CONCANNON, P. W.; HANSEL, W.; VISEK, W. J. The ovarian cycle of the bitch: plasma estrogen, LH and progesterone. Biology of Reproduction, v. 13, p. 112-121, 1975.

CONCANNON, P. W.; MCCANN, J. P.; TEMPLE, M. Biology and endocrinology of ovulation, pregnancy and parturition in the dog. Journal of Reproduction and Fertility, Supplement 39, p. 3-25, 1989.

COUSE J. F.; KORACH K. S. Estrogen receptor null mice: what have we learned and where will they lead us? Endocrinology Review, v. 20, p. 358-417, 1999.

DRUMMOND A. E.; FINDLAY J. K. The role of estrogen in folliculogenesis. Molecular and Cellular Endocrinology, v. 151, p. 57-64, 1999.

DULEBA A. J.; SPACZYNSKI R. Z.; OLIVE D. L.; BEHRMAN H. R. Divergent mechanisms regulate proliferation / survival and steroidogenesis of theca interstitial cells. Molecular Human Reproduction, v. 5, p. 193-198, 1999.

DURRANT, B. S. Semen collection, evaluation and cryopreservation in exotic animal species: maximizing reproductive potential. ILAR Journal, v. 32, n. 1, p. 86-87, 1990.

DURRANT, B. S.; PRATT, N. C.; RUSS, K. D.; BOLAMBA, D. Isolation and 
characterization of canine advanced preantral and early antral follicles.

Theriogenology, v. 49, n. 5, p. 917-932, 1998.

ENGLAND, G. C. W.; VERSTEGEN, J. P.; HEWITT, D. A. Pregnancy following in vitro fertilization of canine oocytes. Veterinary Record, v. 148, n. 1, p. 20-22, 2001.

EVANS, R. M. The steroid and thyroid hormone superfamily. Science, n. 240, n. 3, p. 889-895, 1988.

FARSTAD, W. Assisted reproductive technology in canid species. Theriogenology, v. 53 , n. 2 , p. $175-186,2000$ a.

FARSTAD, W. Current state in biotechnology in canine and feline reproduction. Animal Reproduction Science, v 60-61, n. 1, p. 375-387, 2000b.

GALABOVA-KOVACS, G.; WALTER, I.; AURICH, C.; AURICH, J. E. Steroid receptors in canine endometrial cells can be regulated by estrogen and progesterone under in vitro conditions. Theriogenology, v. 61, n. 4, p. 963-976, 2004.

GILULA, N. B.; EPSTEIN, M. L.; BEERS, W. H. Cell-to-cell communication and ovulation. The Journal of Cell Biology, v. 78, n. 4, p. 58-75, 1978.

GUÉRIN, C. Fécondation in vitro chez la chienne. Où en est-on? Pratique Médicale et Chirurgicale des Animaux de Compagnie, v. 33, n. 1, p. 155-161, 1998.

GUIMARÃES, M. A. B. V. Current research projects and perspectives in reproduction of wild carnivores at the department of animal reproduction of the University of São Paulo. In: INTERNATIONAL SYMPOSIUM ON CANINE AND FELINE REPRODUCTION, 5.0, 2004, São Paulo, 292 p.

HATOYA, S.; TORII, R.; KUMAGAI, D.; SUGIURA, K.; KAWATE, N.; TAMADA, H.; SAWADA, T.; INABA, T. Expression of estrogen receptor $\alpha$ and $\beta$ genes in the mediobasal hypothalamus, pituitary and ovary during the canine estrous cycle. Neuroscience Letters, v. 347, n. 3, p. 131-135, 2003.

HEWITT, D. A.; ENGLAND, G. C. W. Incidence of oocyte nuclear maturation within the ovarian follicle of the bitch. Veterinary Record, v. 143, n. 21, p. 590-591, 1998a.

HEWITT, D. A.; ENGLAND, G. C. W. The canine oocyte penetration assay; its use as an indicator of dog spermatozoal performance in vitro. Animal Reproduction Science, v. 50, n. 1/2, p. 123-139, 1997.

HEWITT, D. A.; ENGLAND, G. C. W. The effect of oocyte size and bitch age upon oocyte nuclear maturation in vitro. Theriogenology, v. 49, n. 5, p. 957-966, $1998 \mathrm{~b}$.

HEWITT, D. A.; WATSON, P. F.; ENGLAND, G. C. W. Nuclear staining and culture requirements for in vitro maturation of domestic bitch oocytes. Theriogenology, $v$. 49, n. 6, p. 1083-1101, 1998.

HYTTEL P.; FAIR T.; CALLESEN H.; GREVE T. Oocyte growth, capacitation and 
final maturation in cattle. Theriogenology, v. 47, n. 10, p. 23-32, 1997.

JEWGENOW, K.; DEHNARD, M.; HILDEBRANDT, T. B.; GÖRITZ, F. Contraception for reproduction control in exotic carnivores. In: INTERNATIONAL SYMPOSIUM ON CANINE AND FELINE REPRODUCTION, 5., 2004, São Paulo. 292 p.

JOHNSTON, S. D.; KIANG, D. T.; SEGUIN, B. E.; HESTAD, R. L. Cytoplasmic estrogen and progesterone receptors in canine endometrium during the estrous cycle. American Journal of Veterinary Research, v.46, p.1653-1658, 1985.

KREGE J. H.; HODGIN J. B.; COUSE J. F.; ENMARK E.; WARNER M.; MAHLER J. F.; SAR M.; KORACH K. S.; GUSTAFSSON J-Å.; SMITHIES O. Generation and reproductive phenotypes of mice lacking estrogen receptor $\beta$. PNAS, v. 95, n. 1, p. 15667-15682, 1998.

LAWRENCE, T. S.; BEERS, W. H.; GILULA, N. B.Transmission of hormonal stimulating by cell-to-cell communication. Nature, v. 272, n. 1, p. 501-506, 1978.

LESEGNO, C. V.; REYNAUD, K.; PECHOUX C.; THOUMIRE, S.; MAILLARD, S. C. Ultrastructure of canine oocytes during in vivo maturation. Molecular Reproduction and Development, 2007. No prelo

LINDE-FORSBERG, C. Intra-uterine insemination in the dog using the scandinavian trans-cervical catheter and a comparison with other methods. Recent Advances in Small Animal Reproduction, 2001. Disponível em: $<$ www.ivis.org $>$ Acesso em: 24 mar. 2005.

LUVONI, G. C. Current progress on assisted reproduction in dogs and cats: in vitro embryo production. Reproduction Nutrition Development, v. 40, n. 1, p. 505-512, 2000.

LUVONI, G. C.; LUCIANO, A. M.; MODINA, S.; GANDOLFI, F. Influence of different stages of the oestrus cycle on cumulus-oocytes on the efficiency of in vitro maturation. Journal of Reproduction and Fertility, v. 5, n.2, p. 141-146, 2001. Supplementum 57.

MINGOTI, G. Z. Maturação oocitária associada à esteroidogênese, papel do soro sangüíneo, albumina sérica e hormônios esteróides. 199953 p. Tese (Doutorado em Fisiologia) - Faculdade de Medicina de Ribeirão Preto, Universidade de São Paulo, São Paulo, 1999.

MOSSELMAN, S.; POLMAN, J.; DIJKEMA, R. ERß: identification and characterization of a novel human estrogen receptor. IFEBS Letters, v. 392, n. 5, p.49-53, 1996.

NICKSON, D. A.; BOYD, J. S.; ECKERSALL, P. D.; FERGUSON, J. M.; HARVEY, M. J.; RENTON, J. P. Molecular biology methods for monitoring oocyte maturation and in 
vitro fertilization in bitches. Journal of Reproduction and Fertility Supplement, v. 47, n. 12, p. 231-240, 1993.

NILSSON, S.; MAKELA, S.; TREUTER, E.; TUJAGUE, M.; THOMSEN, J.; ANDERSSON, G.; ENMARK, E.; PETTERSSON, K.; WARNER, M.; GUSTAFSSON, J. Mechanisms of estrogen action. Physiological Reviews, v. 81, n. 4, p. 1535-1565, 1999.

OLSON, P. N.; HUSTED, P. W.; ALLEN, T. A.; NETT, T. M. Reproductive endocrinology and physiology of the bitch and queen. Veterinary Clinics of North America: Small Animal Practice, v. 14, n. 10, p. 927-946, 1984.

OTOI, T.; FUJII, M.; TANAKA, M.; OOKA, A.; SUZUKI, T. Effect of serum on the in vitro maturation of canine oocytes. Reproduction and Fertility Development, v. 11, n. 9, p. 387-390, 1999.

OTOI, T.; MURAKAMI, M.; FUJII, M.; TANAKA, M.; OOKA, A.; UNE, S.; SUZUKI, T. Development of canine oocytes matures and fertilized in vitro. Veterinary Record, $v$. 146, n. 2, p. 52-53, 2000.

OTOI, T.; OOKA, A.; MURAKAMI, M.; KARJA, N. W. K.; SUZUKI, T. Size distribution and meiotic competence of oocytes obtained from bitch ovaries at various stages of the oestrus cycle. Reproduction and Fertilility Development, v. 13, v. 2-3, n. 10, p. 151-155, 2001.

PELUSO, J. J. Multiplicity of progesterone's actions and receptors in mammalian ovary. Biology of Reproduction, v. 75, n. 5, p. 2-8, 2006.

PEPE, G. J.; BILLIAR, R. B.; LEAVITT, M. G.; ZACHOS, N. C.; GUSTAFSSON, J. A.; ALBRECHT, E. D. Expression of estrogen receptors $\alpha$ and $\beta$ in the baboon fetal ovary. Biology of Reproduction, v. 5, n. 66, p. 1054-1060, 2002.

RENTON, J. P.; BOYD, J. S.; ECKERSALL, P. D.; FERGUSON, J. M.; HARVEY, M. J. A.; MULLANEY, J.; PERRY, B. Ovulation, fertilization and early embryonic development in the bitch (Canis familiaris). Journal of Reproduction Fertility, v. 93, n. 4, p. 221-231, 1991.

REVELLI, A.; PACCHIONI, D.; CASSONI, P.; BUSSOLATI, G.; MASSOBRIO, M. In situ hybridization study of messenger RNA for estrogen receptor and immunohistochemical detection of estrogen and progesterone receptors in the human ovary. Gynecological Endocrinology, v. 10, n. 7, p. 177-186, 1996.

RICHARDS J. S. Perspective: the ovarian follicle - a perspective in 2001. Endocrinology, v 142, n. 24, p. 2184-2193, 2001.

RIZOS, D.; WARD, F.; DUFFY, P.; BOLAND, M. P.; LONERGAN, P. Consequences of bovine oocyte maturation, fertilization or early embryo development in vitro versus in vivo: implications for blastocyst yield and blastocyst quality. Molecular Reproduction and Development, v. 61, n. 12, p. 234-248, 2002. 
RODRIGUES, B. A.; RODRIGUES, J. L. Influence of reproductive status on in vitro oocyte maturation in dogs. Theriogenology, v. 60, n. 1, p. 59-66, 2003.

RODRIGUEZ, K. F.; FARIN, C. E. Gene transcription and regulation of oocyte maturation. Reproduction, Fertility and Development, v. 16, n. 10, p. 55-67, 2004.

SCHAMS, D.; BERISHA, B. Steroids as local regulators of ovarian activity in domestic animals, Domestic Animal Endocrinology. v. 23, n. 1, p. 53-65, 2002.

SCHREIBER J. R.; NAKAMURA K.; ERICKSON G. F. Progestins inhibit FSH stimulated steroidogenesis in cultured rat granulose cells. Molecular Cell Endocrinology, v. 19, n. 10, p. 165-173, 1980.

SIMPSON, I.; ROSE, B.; LOEWENSTEIN, W. R. Size limit of molecules permeating the junctional membrane channels. Science, v. 195, n. 13, p. 294-296, 1977.

STABENFELDT, G. H.; EDQVIST, L. E. Processos Reprodutivos na fêmea. In: SWENSON, M. J.; REECE, W. O. Dukes fisiologia dos animais domésticos. 11. ed. Rio de Janeiro: Ed. Guanabara Koogan S. A., 1996. p. 615-644.

SUTOVSKY, P.; FLECHON, J. E.; FLECHON, B.; MOTLIK, J.; PEYNOT, N.; CHESNE, P.; HEYMAN, Y. Dynamic changes of gap junctions ans cytoskeleton during in vitro culture of cattle oocyte cumulus complexes. Biology Reproduction, v. 49 , n. 6, p. 1277-1287, 1993.

TANI, H.; INABA, T.; MATSUYAMA, S.; TAMAKORI, Y.; TORII, R.; TAHANO, H.; TAMADA, H.; SAWADA, T. Enhancement of estrogen receptor gene expression in the mediobasal hypothalamus during anestrus in the beagle bitch. Neuroscience Letters, v. 22, n. 8, p. 149-152, 1997.

TSUTSUI, T.; HORI, T.; KAWAKAMI, E. Intratubal transplantation of early canine embryos. Jounal of Reproduction Fertility Supplement, v. 14, n. 26, 309-314, 2000.

VANNUCCHI, C. I. Estudo da maturação nuclear in vitro de oócitos de cães em meios suplementados com hormônios e co-cultivo em células homólogas da tuba uterina, 2003. 77 p. Tese (Doutorado em Reprodução Animal) - Faculdade de Medicina Veterinária e Zootecnia, Universidade de São Paulo, São Paulo, 2003.

VERMEIRSCH, H.; SIMOENS, P.; CORYN, M.; VAN DEN BROECK, W. Immunolocalization of progesterone receptors in the canine ovary and their relation to sex steroid hormone concentrations. Reproduction, v. 122,n. 6, p. 73-83, 2001.

WERT, S. E.; LARSEN, W. J. Meiotic resumption and gap junction modulation in the cultured rat cumulus-oocyte complex. Gamete Research, v. 22, n. 2, p. 143-162, 1989.

WIERMAN M. E. Sex steroid effects at target tissues: mechanisms of action. Advances in Physiology Education, v. 31, n. 1, p. 26-33, 2007. 
WILLINGHAM-ROCKY, L. A.; HINRICHS, K.; WESTHUSIN, M. E.; KRAEMER, D. C. Effects of stage of oestrus cycle and progesterone supplementation during culture on maturation of canine oocytes in vitro. Reproduction, v. 126, n. 32, p. 501-508, 2003.

WU, T. C.; WANG, L.; WAN. Y. J. Expression of estrogen receptor gene in mouse oocytes during embryogenesis. Molecular Reproduction Development, v. 50, n. 33, p. 407-412,1992.

WU, T.C.; WANG, L.; WAN, Y. J. Detection of Estrogen receptor messenger ribonucleic acid in human oocytes and cumulus-oocyte complexes using reverse transcriptase-polymerase chain reaction. Fertility and Sterility,v. 1, n. 59, p. 54-59, 1993.

YAMADA, S.; SHIMAZU, Y.; KAWAJI, H.; NAKAZAWA, M.; NAITO, K.; TOYODA, Y. Maturation, fertilization and development of dog oocyte in vitro. Biology of Reproduction, v. 46, n. 5, p. 853-858, 1992.

YANG, P.; WANG. J.; SHEN. Y.; ROY. S. K. Developmental expression of estrogen receptor (ER) and ER in the hamster ovary: regulation by Follicle-Stimulating Hormone. Endocrinology, v. 45, n. 12, p. 5757-5766, 2004. 